University of South Florida

DIGITAL COMMONS

@ UNIVERSITY OF SOUTH FLORIDA
Digital Commons @ University of

South Florida

$1-1-2017$

\title{
Chicago Public Schools (CPS) Travel Training Evaluation Project
}

CUTR

Follow this and additional works at: https://digitalcommons.usf.edu/cutr_nctr

\section{Recommended Citation}

"Chicago Public Schools (CPS) Travel Training Evaluation Project," National Center for Transit Research (NCTR) Report No. CUTR-NCTR-RR-2014-02, Center for Urban Transportation Research, University of South Florida, 2017.

DOI: https://doi.org/10.5038/CUTR-NCTR-RR-2014-02

Available at: https://scholarcommons.usf.edu/cutr_nctr/63

This Technical Report is brought to you for free and open access by the National Center for Transit Research (NCTR) Archive (2000-2020) at Digital Commons @ University of South Florida. It has been accepted for inclusion in Research Reports by an authorized administrator of Digital Commons @ University of South Florida. For more information, please contact digitalcommons@usf.edu. 


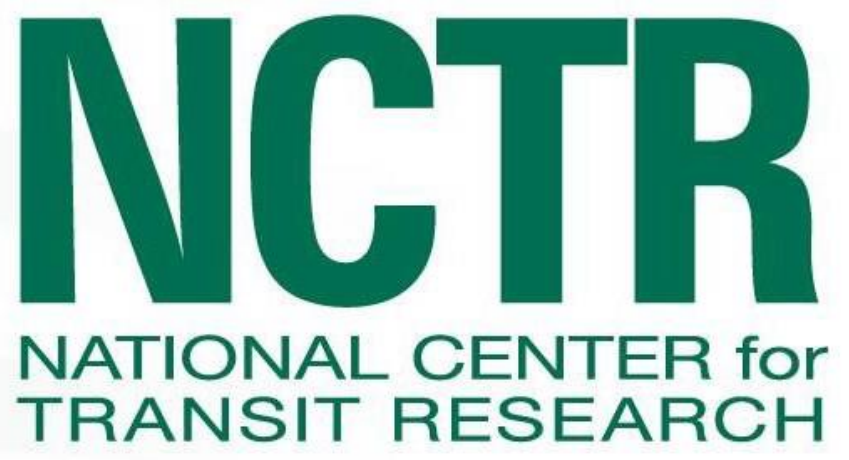

\section{CPS Travel Training Evaluation Project}

\section{January 2017}

PROJECT NO.

2117-9050-02-C

PREPARED FOR

National Center for Transit Research (NCTR) 


\section{Disclaimer}

The contents of this report reflect the views of the authors, who are responsible for the facts and the accuracy of the information presented herein. This document is disseminated under the sponsorship of the Department of Transportation University Transportation Centers Program and the Florida Department of Transportation, in the interest of information exchange. The U.S. Government and the Florida Department of Transportation assume no liability for the contents or use thereof.

The opinions, findings, and conclusions expressed in this publication are those of the authors and not necessarily those of the State of Florida Department of Transportation. 


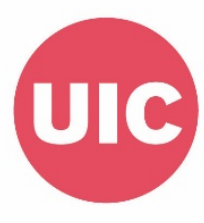

\section{Urban Transportation Center}

THE URBAN TRANSPORTATION CENTER AT

THE UNIVERSITY OF ILLINOIS AT CHICAGO

\section{CPS Travel Training Evaluation Project}

January 2017

UIC 2117-9050-02-C

\section{Prepared For}

National Center for Transit Research

Center for Urban Transportation Research

University of South Florida 


\section{Technical Report Documentation}

\begin{tabular}{|c|c|c|c|c|}
\hline $\begin{array}{c}\text { 1. Report No. } \\
\text { UIC 2117-9050-02-C }\end{array}$ & \multicolumn{2}{|c|}{ 2. Government Accession No. } & \multicolumn{2}{|c|}{$\begin{array}{l}\text { 3. Recipient's Catalog } \\
\text { No. }\end{array}$} \\
\hline \multicolumn{2}{|c|}{ 4. Title and Subtitle } & \multicolumn{3}{|c|}{ 5. Report Date } \\
\hline \multicolumn{5}{|c|}{ 6. Performing Organization Code } \\
\hline \multicolumn{2}{|c|}{$\begin{array}{l}\text { 7. Author(s) } \\
\text { Urban Transportation Center } \\
\text { University of Illinois at Chicago } \\
412 \text { S. Peoria Street, Suite } 240 \\
\text { Chicago, IL } 60607\end{array}$} & \multicolumn{3}{|c|}{$\begin{array}{l}\text { 8. Performing Organization Report No. } \\
\text { UIC 2117-9050-02-C }\end{array}$} \\
\hline \multicolumn{2}{|c|}{$\begin{array}{l}\text { 9. Performing Organization Name and Address } \\
\text { National Center for Transit Research } \\
\text { Center for Urban Transportation Research (CUTR) } \\
\text { University of South Florida } \\
\text { 4202 East Fowler Avenue, CUT100 } \\
\text { Tampa, FL 33620-5375 }\end{array}$} & \multicolumn{3}{|c|}{ 10. Work Unit No. (TRAIS) } \\
\hline \multicolumn{5}{|c|}{ 11. Contract or Grant No. } \\
\hline \multicolumn{2}{|c|}{$\begin{array}{l}\text { 12. Sponsoring Agency Name and Address } \\
\text { Research and Innovative Technology Administration } \\
\text { U.S. Department of Transportation } \\
\text { Mail Code RDT-30, } 1200 \text { New Jersey Ave SE, Room } \\
\text { E33 } \\
\text { Washington, DC 20590-0001 }\end{array}$} & \multicolumn{3}{|c|}{ 13. Type of Report and Period Covered } \\
\hline \multicolumn{5}{|c|}{ 14. Sponsoring Agency Code } \\
\hline \multicolumn{5}{|l|}{ 15. Supplementary Notes } \\
\hline \multicolumn{5}{|l|}{ 16. Abstract } \\
\hline \multicolumn{5}{|c|}{$\begin{array}{l}\text { Public transportation and public educational programs are mandated to provide transportation services } \\
\text { for mentally and physically disabled individuals. While programs to transport members of disabled } \\
\text { populations are important to ensure access to and participation in important educational and work } \\
\text { related activities, they are often highly expensive to operate. Moreover, they do not necessarily increase } \\
\text { the independence of disabled clients. For these reasons, transit agencies, employers and educational } \\
\text { institutions have begun to develop training programs to teach qualified clients how to use the fixed } \\
\text { public transit system. Movement of disabled riders to fixed public transit systems reduces demand of } \\
\text { costly paratransit programs, increases the ability of disabled clients to function independently, and may } \\
\text { have a multitude of other benefits. }\end{array}$} \\
\hline \multicolumn{2}{|l|}{ 17. Key Words } & \multicolumn{3}{|c|}{$\begin{array}{l}\text { 18. Distribution Statement } \\
\text { No restrictions }\end{array}$} \\
\hline $\begin{array}{l}\text { 19. Security Classification } \\
\text { (of this report) }\end{array}$ & $\begin{array}{l}\text { 20. Security Classification } \\
\text { (of this page) }\end{array}$ & $\begin{array}{l}\text { 21. No. of } \\
90\end{array}$ & & 22. Price \\
\hline Unclassified & & & & \\
\hline
\end{tabular}


Metric Conversion

\begin{tabular}{|c|c|c|c|c|}
\hline SYMBOL & WHEN YOU KNOW & MULTIPLY BY & TO FIND & SYMBOL \\
\hline \multicolumn{5}{|c|}{ LENGTH } \\
\hline in & inches & 25.4 & millimeters & $\mathrm{mm}$ \\
\hline ft. & feet & 0.305 & meters & $\mathrm{m}$ \\
\hline yd. & yards & 0.914 & meters & $\mathrm{m}$ \\
\hline mi & miles & 1.61 & kilometers & $\mathrm{km}$ \\
\hline \multicolumn{5}{|c|}{ VOLUME } \\
\hline fl. oz. & fluid ounces & 29.57 & milliliters & $\mathrm{mL}$ \\
\hline gal & gallons & 3.785 & liters & $\mathrm{L}$ \\
\hline $\mathrm{ft}^{3}$ & cubic feet & 0.028 & cubic meters & $\mathrm{m}^{3}$ \\
\hline$y d^{3}$ & cubic yards & 0.765 & cubic meters & $\mathrm{m}^{3}$ \\
\hline \multicolumn{5}{|c|}{ NOTE: volumes greater than $1000 \mathrm{~L}$ shall be shown in $\mathrm{m}^{3}$} \\
\hline \multicolumn{5}{|c|}{ MASS } \\
\hline oz. & ounces & 28.35 & grams & $\mathrm{g}$ \\
\hline lb. & pounds & 0.454 & kilograms & $\mathrm{kg}$ \\
\hline $\mathbf{T}$ & Short tons (2000 lb.) & 0.907 & $\begin{array}{c}\text { megagrams } \\
\text { (or "metric ton") }\end{array}$ & Mg (or "t") \\
\hline \multicolumn{5}{|c|}{ TEMPERATURE (exact degrees) } \\
\hline${ }^{\circ} \mathbf{F}$ & Fahrenheit & $\begin{array}{c}5(F-32) / 9 \\
\text { or }(F-32) / 1.8\end{array}$ & Celsius & ${ }^{\circ} \mathrm{C}$ \\
\hline
\end{tabular}




\title{
Project Report \\ CPS Travel Training Evaluation Project
}

\author{
Eric W. Welch \\ Professor and Director \\ Center for Science, Technology and Environmental Policy Studies (CSTEPS) \\ School of Public Affairs, Arizona State University, Phoenix, Arizona \\ P.S. Sriraj \\ Interim Director \\ Associate Research Professor \\ Urban Transportation Center (UTC) \\ University of Illinois at Chicago, Chicago, Illinois \\ Chul Hyun Park \\ PhD Student \\ Arizona State University, School of Public Affairs, Phoenix Arizona \\ Brian Tomkins \\ Master's Student \\ Urban Transportation Center (UTC) \\ University of Illinois at Chicago, Chicago, Illinois
}

\section{Introduction}

Public transportation and public educational programs are mandated to provide transportation services for mentally and physically disabled individuals. While programs to transport members of disabled populations are important to ensure access to and participation in important educational and work related activities, they are often highly expensive to operate. Moreover, they do not necessarily increase the independence of disabled clients. For these reasons, transit agencies, employers and educational institutions have begun to develop training programs to teach qualified clients how to use the fixed public transit system. Movement of disabled riders to fixed public transit systems reduces demand of costly paratransit programs, increases the ability of disabled clients to function independently, and may have a multitude of other benefits.

Travel training programs (TTP), particularly those offered by public school systems, are in their infancy. Chicago Public School's (CPS) TTP is one of the oldest in existence. While there is ad 
hoc evidence that these programs are beneficial in many respects, to date there has been little effort to develop a theoretically informed TTP evaluation framework or to formally assess the costs and benefits of these programs. Due in part to this lack of attention, constant fiscal constraints on public agencies make travel training programs vulnerable to underfunding or closure.

In response, this project undertook a systematic effort to place TTP evaluation on a more professionally recognizable and practically implementable footing. The project was conducted in two tracks: design of an evaluation framework for any TTP that can be applied to any TTP in existence and a basic analysis of an existing TTP to demonstrate current application and opportunities for improvement. The first track creates an evaluation plan, logic model and a set of possible metrics for evaluation while the second track explores how the CPS TTP evaluation effort addresses some key evaluation questions and suggests revisions in line with the framework.

This report is divided in to five sections: introduction, data and methods, evaluation framework including the logic model and metrics, and CPS TTP data analysis and review. Appendices include some CPS TTP documents, the Institutional Review Board approvals and an academic paper that integrates literature, current state of the art and the evaluation framework.

\section{Data and Methods}

The project was conducted as a two track design in which the first track provided a framework for evaluation while the second undertook basic analysis of existing CPS TTP data.

\section{Track 1. Framework for Evaluation}

The evaluation framework was developed as the result of a comprehensive literature review and the iterative development of a logic model and a menu of metrics and methods.

Literature review. The overall project began with an initial foray into the literature pertaining to travel training programs. This included a review of TTPs that have implemented around the 
country, including those that operate in public school systems. Additionally, the project undertook a review of the evaluation literature with the goal of organizing a formal evaluation approach that incorporated the theoretical integration of program goals, resources, activities, outputs and outcomes. The literature review informed the overall evaluation design and resulted in an integrative theory-driven framework for evaluating travel training programs.

Logic model. Based on the literature review and the theory-driven framework, the evaluation team developed an initial generic logic model relevant for TTPs. The logic model is a broadly accepted approach to linking inputs and activities to outputs to outcomes to outcomes. Inputs are the financial, technical, financial, human resources necessary to implement the TTP. Activities are broadly conceived as mechanisms that link objectives to actions. Outputs are immediate products of project activities while outcomes represent the effect that outputs have on the broader context or environment at which the activities are aimed or embedded. Outcomes are the project results that affect longer term goals. The logic model developed for this project includes short, medium and long term outcomes.

Metrics and Methods. As part of the evaluation framework, the project developed a comprehensive list of metrics and measures that could be used by TTPs. Additionally, the project suggests different types of methods typically employed for evaluation and highlights those that have been used for TTP evaluation in the past. The framework is flexible such that agencies or organizations wishing to apply the framework can select metrics and methods depending on specific needs and interests.

\section{Track 2. Basic Analysis of Chicago Public Schools TTP Data}

Based on data collected from the CPS TTP, the project presents a practical example of current evaluation efforts, some basic statistics and reflections about the CPS data collection in light of the evaluation framework.

Data collection. The project was provided two years of student-level data from the Chicago Public Schools’ TTP evaluation system. Data include the following fields 
- Student age

- Primary disability

- Gender

- Whether the student passed eligibility assessment and began training

- School year trained or assessed

- Whether student completed training and began traveling independently

- Date of completion or removal from program

- Reason student did not pass assessment or complete training

- Anticipated graduation date

- Case manager notification date

- Transition plan revision date

- Whether student was removed from transportation services in impact

- Number of training days

- Region (NE, NW, SE and SW)

- Number of buses or trains to school

- Number of buses or trains from school

Analysis: The analysis presented in this report provides a basic statistics from the collected data. Additionally, the analysis section reviews and reflects on the data collected in light of the evaluation framework. It concludes by identifying opportunities for augmenting the CPS data collection plan for the evaluation.

\section{Evaluation team}

The project was coordinated by Eric Welch and PS Sriraj. Additionally, the project hired one $\mathrm{PhD}$ level and one Master level graduate student part time. Under supervision, the students conducted the literature reviews and analyzed the evaluation data.

Eric Welch is the Director of the Center for Science Technology and Environmental Policy Studies and Professor of Public Affairs at Arizona State University. His research interests 
include extreme weather and transit; transit safety; alternative fuels; transit program evaluation; travel training; slow zone and construction impacts on ridership, mobility of low income, minority, and dependent riders. P. S. Sriraj is Research Associate Professor and Director of the Urban Transportation Center, Director of Research, Director of the Metropolitan Transportation Support Initiative (METSI) at the University of Illinois at Chicago. He has published extensively on public transportation systems, welfare-to-work, transportation asset management, GIS in transportation, socio-economic factors, and addressing systems thinking/complex problems. Chul Hyun Park is a PhD student in Public Administration and Policy at Arizona State University. His research focuses on program evaluation, collaborative governance, and information and communication technology in emergency and disaster management. Brian Tompkins earned a Master's in Public Administration degree from the University of Illinois at Chicago in the fall of 2016. He currently holds the position of project assistant with the Metropolitan Mayors Caucus, a non-profit planning organization representing Chicago area municipalities on environmental and housing issues. 


\section{Track 1: Literature review, evaluation framework and logic model Increasing the Mobility of the Disabled on Public Transit: Travel Training Programs}

\section{Introduction}

Public transportation provides individuals with opportunities to travel from and to their homes, schools, workplaces, and other places. However, people with disabilities have difficulty using public transportation and are likely to be excluded from the conveniences of public transportation. Such mobility issues are also associated with the inequality of opportunity for work, leisure, education, and socialization. As an alternative for addressing such social problems, travel training, a short-term training to teach people with disabilities independent travel skills required to use fixed-route transportation, were developed in the 1970s and have spread across the United States. This summary provides a brief description of travel training and its benefits and a theory-driven framework for evaluating the training programs to help evaluators and practitioners examine the effectiveness and efficiency of the training programs and improve program implementation. It also provides a full logic model developed by the project. The full literature review and framework are presented in Appendix 1.

\section{Travel Training Programs}

Travel training programs provide short-term, comprehensive, and intensive training sessions designed to teach trainees how to use fixed-route public transportation safely and independently. Training program providers include public schools, school districts, local transportation authorities, human and social service agencies, for-profit organizations, and nonprofits advocating for people with disabilities. To receive the training services, individuals with disabilities or their parents and guardians need to apply for the training program. Following the application process, the individuals' needs, skills and travel routes are thoroughly assessed by travel training instructors to determine the eligibility for travel training. If travel training is recommended as a result of the pre-assessments, personalized travel training plans are developed in collaboration among the instructors, parents or guardians, and physical or occupational therapists. Then, travel training instructors carry out their training sessions. In general, travel training consists of in-class and on-site training sessions. Finally, instructors evaluate whether 
their trainees are able to travel independently and safely by using fixed-route transportation. If a trainee has knowledge and skills necessary for independent and safe travel, he or she is recommended to travel alone.

Travel training programs are expected to create a variety of benefits for trainees, their parents or guardians, public transportation agencies, schools and the community at large. Travel training provides trainees with opportunities to attend schools for post-secondary education, to get a job, and to enjoy various social activities. Travel training reduces parents’ and guardians’ care responsibilities. As trained individuals switch to fixed-route public transportation, local transportation agencies can reduce the operating costs of paratransit services that is required by federal laws and more costly than fixed-route transportation services. Schools and school districts can reduce their administrative and human resource costs for providing individualized transportation services for students with disabilities (e.g., individualized education programs (IEPs)). The benefits for the community at large include "more people in employment or education...[and] increased use of sustainable travel modes” (AECOM, 2011, p. vii).

\section{A Theory-Driven Approach for Evaluating Travel Training Programs}

Travel training programs are characterized by high variability in program context, content, delivery system, and outcome. Moreover, over the past decades, a wider range of actors from the nonprofit and for-profit sectors have engaged in designing and implementing travel training programs. In such conditions, theory-driven evaluation can be useful and appropriate for evaluating travel training programs. Such an approach to evaluation "first attempts to map out the programme theory lying behind the intervention and then design a research evaluation to test out that theory” (Walshe, 2007, p. 58). Theory-driven evaluation aims to not only determine whether a program works, but also understand when, how, and why a program works. Therefore, this summary provides an integrative theory-based evaluation framework for travel training programs.

The framework for evaluating travel training programs consists of three dimensions: production and delivery of travel training; outcomes and benefits; and factors that influence the relationship between travel training and its outcomes (See Figure 1). First, the training production and delivery dimension includes organizational-level factors, individual-level factors 
and training-related factors. Organization-level factors consider types of training providers, approaches to travel training, and financial sustainability. Individual-level factors concern instructors' skills and competencies. Training-related factors include training models, contents and aids. As the second dimension of the framework, travel training programs have a wide range of short-term, intermediate, and long-term impacts on individual trainees, parents or guardians, schools and school districts, training providers, local public transportation authorities, other public agencies at the three levels of government, and the community at large. Lastly, there are various individual, inter-organizational, and environmental factors that can influence the effectiveness and efficiency of travel training programs, including travel infrastructure and environment, trainees' characteristics, involvement of parents and guardians and collaboration and partnership among stakeholders.

\section{Logic Model}

The logic model for travel training programs moves beyond the theory-driven evaluation framework to specify the elements of the framework into resources, activities, outputs and outcomes. This logic model includes more detailed information and knowledge about the respective phases of travel training programs. The logic model takes into account a variety of stakeholders: individual trainees, parents, guardians and caregivers, schools and school districts, training program providers, public transportation authorities, other public agencies at the three levels of government, collaborations and partnerships, and the community at large. The logic model also considers short-term (1 through 3 years), intermediate (4 through 6 years), and longterm (7 through 10 years) outcomes. The full logic model is presented in Table 1.

The logic model consists of a wide range of factors related to travel training. To prioritize these factors, evaluators first need to figure out key characteristics of the production and delivery of travel training, such as the types of travel training providers (public agencies, nonprofit organizations, or for-profit organizations), approaches to travel training (in-house or contracting-out training), and training models (informational presentation, one-on-one training, or peer-to-peer training). These key characteristics help evaluators focus on more important factors in specific evaluation contexts regarding resources, activities, and outputs in the logic model. For example, if an evaluator assesses an in-house travel training program in which a 
local public agency provides training services on its own, the evaluator would not need to pay attention to factors related to collaboration and partnership across the public, nonprofit, and forprofit sectors in the logic model.

\section{Conclusion}

This summary described travel training and its benefits and provided an integrative theorydriven framework for evaluating travel training programs. It also presented the logic model guided by the framework. The framework and logic model can be used to design and implement summative evaluation to determine the merit and worth of travel training programs. The framework helps scholars and practitioners investigate not only whether the programs work, but also when, how, and why the programs work, thus providing the contingent and situational information of program effectiveness and efficiency. The logic model provides a guide for developing a full evaluation plan.

\section{References}

AECOM. (2011). Travel training: Good practice guidance. London, U.K. Retrieved from https://www.gov.uk/government/uploads/system/uploads/attachment_data/file/4482/guidanc e.pdf

Walshe, K. (2007). Understanding what works-and why-in quality improvement: The need for theory-driven evaluation. International Journal for Quality in Health Care, 19(2), 57-59. doi:10.1093/intqhe/mzm004 


\section{Figure1: Integrative Theory-Driven Framework for Evaluating Travel Training Programs}

\begin{tabular}{|c|c|c|}
\hline \multirow[b]{3}{*}{$\begin{array}{l}\text { Production and Delivery of } \\
\text { Travel Training Program }\end{array}$} & $\begin{array}{l}\text { Factors that Influence the Relationship } \\
\text { between Travel Training and Its Outcomes }\end{array}$ & Outcomes and Benefits \\
\hline & $\begin{array}{l}\text { Travel Infrastructure and Environment } \\
\text { - Training in rural and suburban areas } \\
\text { - Length and easy of the journey } \\
\text { Individual Trainees' Characteristics } \\
\text { - Age } \\
\text { - Type and severity of disability } \\
\text { - Anxiety and fear towards training } \\
\text { - Motivation and commitment to training } \\
\text { - Learning style }\end{array}$ & $\begin{array}{l}\text { Individual Trainees } \\
\text { - Trainees' satisfaction with travel training } \\
\text { - Changes in attitudes towards independent travel } \\
\text { - Increased use of fixed-route public transportation } \\
\text { - Increased access to healthcare and social services, } \\
\text { education, employment, goods and services, and social } \\
\text { activities } \\
\text { - Increased self-confidence and self-esteem } \\
\text { - Decreased likelihood of developing problem behavior } \\
\text { - Saved money }\end{array}$ \\
\hline & $\begin{array}{l}\text { - Prior experience of using public transportation } \\
\text { Parent/Guardian behavior and Involvement } \\
\text { - Overprotection, resistance, and anxiety } \\
\text { - Communication with training instructors } \\
\text { - Trust in training instructors }\end{array}$ & $\begin{array}{l}\text { Parents/Guardians } \\
\text { - Reduced care responsibilities } \\
\text { - Increased time and opportunities for education, } \\
\text { employment, and social activities } \\
\text { - Improved economic, mental, and social wellbeing } \\
\end{array}$ \\
\hline \multirow{2}{*}{$\begin{array}{l}\text { Organization-level Factors } \\
\text { - Types of travel training providers } \\
\text { - Approaches to travel training } \\
\text { - Financial sustainability }\end{array}$} & \multirow{3}{*}{$\begin{array}{l}\text { Collaboration and Partnership among Stakeholders } \\
\text {-The context and environment (i.e. resource conditions, } \\
\text { program legal frameworks, pre-history of } \\
\text { collaboration, and network connectedness) } \\
\text { - The collaborative process (i.e. communication and } \\
\text { deliberation, mutual trust, shared understanding, and } \\
\text { leadership) }\end{array}$} & $\begin{array}{l}\text { Schools and School Districts } \\
\text { - Financial, administrative, and human resource cost } \\
\text { saving and avoidance } \\
\text { - Positive classroom/school climate }\end{array}$ \\
\hline & & \multirow{2}{*}{$\begin{array}{l}\text { Travel Training Providers } \\
\text { - Financial sustainability } \\
\text { - Positive recognition and reputation }\end{array}$} \\
\hline \multirow{3}{*}{$\begin{array}{l}\text { Instructors' Skills and Competencies } \\
\text { - Knowledge about disabilities, the transportation system, } \\
\text { and travel skills and techniques } \\
\text { - Environmental and risk analysis } \\
\text { - Planning personalized instruction } \\
\text { - Pre- and post-evaluation } \\
\text { - Administration and supervision of travel training }\end{array}$} & & \\
\hline & & $\begin{array}{l}\text { Public Transportation Authorities and Operators } \\
\text { - Financial saving and avoidance } \\
\text { - Increase in public transportation patronage } \\
\text { - Positive political supports }\end{array}$ \\
\hline & & \multirow{2}{*}{$\begin{array}{l}\text { Other Public Agencies at the Three Levels of } \\
\text { Governments } \\
\text { - Reduced reliance on social welfare benefits } \\
\text { - Reduced government spending for medical services } \\
\text { - Increased public revenues }\end{array}$} \\
\hline \multirow[t]{2}{*}{$\begin{array}{l}\text { Training-related Factors } \\
\text { - Training models } \\
\text { - Training contents and topics } \\
\text { - Training aids and tools }\end{array}$} & & \\
\hline & & $\begin{array}{l}\text { Community at Large } \\
\text { - Improved social inclusion } \\
\text { - Economic benefits } \\
\text { - Environmental benefits }\end{array}$ \\
\hline
\end{tabular}


Table 1. A Logic Model for Travel Training Programs

\begin{tabular}{|c|c|c|}
\hline Resources & Activities & Outputs \\
\hline $\begin{array}{l}\text { Trainees } \\
\text {-Motivation for training } \\
\text {-Cognitive and physical skills } \\
\text {-Prior experience with public transportation }\end{array}$ & $\begin{array}{l}\text { Trainees } \\
\text {-Get information of and applying for training } \\
\text {-Attend pre-assessment, classroom and onsite training, and } \\
\text { post-evaluation }\end{array}$ & \multirow{8}{*}{$\begin{array}{l}\text {-Quality of a recruitment plan made by the } \\
\text { training providers } \\
\text {-Number and quality of brochures and } \\
\text { flyers for recruitment } \\
\text {-Number and quality of curriculum and } \\
\text { learning resources } \\
\text {-Number of application packets reviewed by } \\
\text { the training providers } \\
\text {-Number of enrolled trainees } \\
\text {-Number and quality of pre-assessments } \\
\text {-Number and quality of individualized goals } \\
\text { and training plans developed } \\
\text {-Number and quality of classroom and } \\
\text { onsite training sessions } \\
\text {-Number and quality of post-evaluations } \\
\text {-Numbers and quality of follow-up services } \\
\text {-Number of trainees who complete training }\end{array}$} \\
\hline $\begin{array}{l}\text { Parents, Guardians, and Caregivers } \\
\text {-Time spent for helping trainees attend training } \\
\text {-Personal vehicles to take trainees to trainers } \\
\text {-Emotional supports for trainees }\end{array}$ & $\begin{array}{l}\text { Parents, Guardians, and Caregivers } \\
\text {-Get information of and applying for training } \\
\text {-Give trainees rides to attend training } \\
\text {-Provide emotional supports }\end{array}$ & \\
\hline $\begin{array}{l}\text { Schools and School Districts (regarding } \\
\text { students with disabilities) } \\
\text { - Teachers } \\
\text { - Administrative staff for individualized } \\
\text { education programs (IEP) } \\
\text { - Budgets for training }\end{array}$ & $\begin{array}{l}\text { Schools and School Districts (regarding students with } \\
\text { disabilities) } \\
\text {-Provide parents and guardians with information and } \\
\text { consulting services of training } \\
\text {-Administrative services regarding the training applications } \\
\text { and changes in students' IEP as a result of travel trainings } \\
\text {-Creating and managing budgets for training }\end{array}$ & \\
\hline $\begin{array}{l}\text { Training Providers } \\
\text {-Trainers and administrative staff } \\
\text {-Grants for operating training } \\
\text {-Occupancy/utilities, education materials, and } \\
\text { office supplies }\end{array}$ & $\begin{array}{l}\text { Training Providers } \\
\text {-Recruiting trainees } \\
\text {-Developing curriculum, learning resources, and instructional } \\
\text { materials } \\
\text {-Conducting pre-assessment and environmental analysis } \\
\text {-Developing individualized goals and training plans } \\
\text {-Classroom and one-on-one training } \\
\text {-Post-evaluation and final written evaluation report } \\
\text {-Hiring trainers, supervisors, and administrative staff } \\
\text {-Continuing education (e.g., attending conferences and } \\
\text { workshops) } \\
\text {-Applying for and accepting grants, managing personnel } \\
\text { expenses, accounting, and paying for occupancy/utilities/ } \\
\text { purchasing and managing equipment, materials, and supplies }\end{array}$ & \\
\hline $\begin{array}{l}\text { Public Transportation Authorities } \\
\text { - Fixed-route transportation systems } \\
\text { - Reduced fare and/or free rider permits for } \\
\text { trainees and instructors } \\
\text { - Budgets for training }\end{array}$ & $\begin{array}{l}\text { Public Transportation Authorities } \\
\text {-Providing equipment for trainees (e.g., wheelchair lifts and } \\
\text { kneeling capability) } \\
\text {-Training bus drivers to assist trainees to board and stay safe } \\
\text { on the bus } \\
\text {-Issuing reduced fare and/ or free rider permits for trainees } \\
\text { and trainers } \\
\text {-Creating and managing budgets for the training programs }\end{array}$ & \\
\hline $\begin{array}{l}\text { Other Public Agencies at the Three Levels of } \\
\text { Government } \\
\text { - Human, financial, and in-kind resources from } \\
\text { other public agencies to support training }\end{array}$ & $\begin{array}{l}\text { Other Public Agencies at the Three Levels of Government } \\
\text {-Assigning public employees to assist training } \\
\text {-Allocating local, state, and/or federal funds to operating } \\
\text { training } \\
\text { - Donating in-kind resources }\end{array}$ & \\
\hline $\begin{array}{l}\text { Collaboration and Partnership } \\
\text {-Referral and communication systems } \\
\text {-Prior history of collaboration/partnership - } \\
\text {-Shared understanding } \\
\text {-Commitment to the training programs } \\
\text {-Mutual trust }\end{array}$ & $\begin{array}{l}\text { Collaboration and Partnership } \\
\text {-Referring people to the training providers } \\
\text {-Making a contracting-out agreement with contractors } \\
\text {-Allocating financial resources to contractors } \\
\text {-Monitoring and evaluating the training programs } \\
\text {-Mobilizing shared resources }\end{array}$ & \\
\hline $\begin{array}{l}\text { Community at Large } \\
\text {-Community culture promoting diversity } \\
\text {-Political supports for the travel training } \\
\text { programs } \\
\text {-Volunteers who willingly commit their spare } \\
\text { time and resources to the travel training } \\
\text { programs (e.g., volunteer trainers) }\end{array}$ & $\begin{array}{l}\text { Community at Large } \\
\text {-Carrying out a non-political and political campaign for the } \\
\text { training programs } \\
\text {-Establishing a group of volunteers and supporters for the } \\
\text { training programs }\end{array}$ & \\
\hline
\end{tabular}




\section{Table 1. A Logic Model for Travel Training Programs (continued)}

\begin{tabular}{|c|c|c|}
\hline Short-term Outcomes & Intermediate Outcomes & Long-term outcomes \\
\hline $\begin{array}{l}\text { Trainees } \\
\text { Benefits for both people with disabilities and } \\
\text { older people } \\
\text {-Satisfaction with application/referral, pre- } \\
\text { assessments, individualized training planning, } \\
\text { classroom and onsite training, and post- } \\
\text { evaluation } \\
\text {-Changes in attitudes towards traveling } \\
\text { independently } \\
\text {-Increased knowledge and skills } \\
\text {-Increased uses of fixed-route public } \\
\text { transportation } \\
\text {-Increased moderate-intensity physical activity }\end{array}$ & $\begin{array}{l}\text { Trainees } \\
\text { Benefits for both people with disabilities and older } \\
\text { people } \\
\text {-Increased access to healthcare and public social } \\
\text { services, markets for goods and services, and social and } \\
\text { leisure activities } \\
\text {-Increased independence, confidence, and self-esteem } \\
\text {-Saved money from increased access to a wider range of } \\
\text { stores } \\
\text {-Cost avoidance due to increased access to services } \\
\text { Benefits for students with disabilities } \\
\text {-Increased access to post-secondary education and } \\
\text { training and employment } \\
\text {-Decreased likelihood of developing behavior problems } \\
\text { Benefits for older people } \\
\text {-Aging in place } \\
\text {-Reduced or deferred costs of nursing homes } \\
\end{array}$ & $\begin{array}{l}\text { Trainees (both people with disabilities and older } \\
\text { people) } \\
\text {-Improved economic opportunities and benefits } \\
\text {-Improved physical, mental, and social well-being }\end{array}$ \\
\hline $\begin{array}{l}\text { Parents, Guardians, and Caregivers } \\
\text {-Reduction in care responsibilities }\end{array}$ & $\begin{array}{l}\text { Parents, Guardians, and Caregivers } \\
\text {-More time and opportunities for education and training, } \\
\text { employment, and social, recreational, and leisure } \\
\text { activities }\end{array}$ & $\begin{array}{l}\text { Parents, Guardians, and Caregivers } \\
\text {-Improved economic opportunities and benefits } \\
\text {-Improved mental and social well-being }\end{array}$ \\
\hline $\begin{array}{l}\text { Schools and School Districts (regarding } \\
\text { students with disabilities) } \\
\text {-More engaged and motivated students with } \\
\text { disabilities } \\
\text {-Decreased students with disabilities using } \\
\text { school buses } \\
\text {-Decreased students in the list of the } \\
\text { transportation section of the individual } \\
\text { education program }\end{array}$ & $\begin{array}{l}\text { Schools and School Districts (regarding students with } \\
\text { disabilities) } \\
\text {-Positive classroom/school climate } \\
\text {-Reduced cost of operating school bus for student with } \\
\text { disabilities } \\
\text {-Reduction in administrative and human resource costs }\end{array}$ & $\begin{array}{l}\text { Schools/Colleges (regarding students with } \\
\text { disabilities) } \\
\text {-Positive classroom/school climate } \\
\text {-Cost savings from the reduced use of school bus } \\
\text {-Cost savings from the reduction in administrative } \\
\text { and human resource costs }\end{array}$ \\
\hline $\begin{array}{l}\text { Training Providers } \\
\text {-Increase in the number of students applying to } \\
\text { the programs }\end{array}$ & $\begin{array}{l}\text { Training Providers } \\
\text {-Increased funding for the programs }\end{array}$ & $\begin{array}{l}\text { Training Program Providers } \\
\text {-Financial sustainability of the programs } \\
\text {-Improved public recognition and reputation }\end{array}$ \\
\hline \multirow[t]{2}{*}{$\begin{array}{l}\text { Public Transportation Authorities } \\
\text {-Reduced costs of operating paratransit } \\
\text { services }\end{array}$} & $\begin{array}{l}\text { Public Transportation Authorities } \\
\text {-Increase in revenue from the increased use of fixed- } \\
\text { route public transit } \\
\text {-Reduced costs of operating paratransit services }\end{array}$ & $\begin{array}{l}\text { Public Transportation authorities } \\
\text {-Financial sustainability } \\
\text {-Increased public supports }\end{array}$ \\
\hline & $\begin{array}{l}\text { Other Public Agencies at the Three Levels of } \\
\text { Government } \\
\text {-Reduced reliance on welfare benefits owing to } \\
\text { improved economic opportunities } \\
\text {-Reduced demand on social and medical services due to } \\
\text { improved physical and mental health }\end{array}$ & $\begin{array}{l}\text { Other Public Agencies } \\
\text {-Cost avoidance from reduced reliance on welfare } \\
\text { benefits } \\
\text {-Cost avoidance from reduced demand on social } \\
\text { and medical services } \\
\text {-Increased revenue from paying more taxes due to } \\
\text { improved economic opportunities (e.g., property } \\
\text { taxes, sales taxes, and income taxes) }\end{array}$ \\
\hline \multirow[t]{2}{*}{$\begin{array}{l}\text { Collaboration and Partnership } \\
\text {-Enhanced communication, shared } \\
\text { understanding, and mutual trust }\end{array}$} & $\begin{array}{l}\text { Collaboration and Partnership } \\
\text {-Increase in shared resources }\end{array}$ & $\begin{array}{l}\text { Collaboration and Partnership } \\
\text {-Improved collaborative capacity for providing the } \\
\text { training programs }\end{array}$ \\
\hline & $\begin{array}{l}\text { Community at Large } \\
\text {-Increase in a well-educated workforce } \\
\text {-Spending more in local markets and stores } \\
\text {-Environmental benefits due to increased use of } \\
\text { sustainable transportation (e.g., reduction in CO2 } \\
\text { emissions) } \\
\text {-Increased diversity of people involving the community }\end{array}$ & $\begin{array}{l}\text { Community at Large } \\
\text {-Long-term economic benefits from a well- } \\
\text { educated workforce and increase in trainees' } \\
\text { spending } \\
\text {-Long-term environmental benefits from increased } \\
\text { use of sustainable transportation } \\
\text {-Building a community of diversity }\end{array}$ \\
\hline
\end{tabular}




\section{Track 2: Analysis of Travel Training Program Evaluation Data Presenting and Assessing Chicago Public Schools Travel Training Programs}

An integrative-theory driven framework (Figure 2) for evaluating travel training programs was built based on the basis of prior studies on travel training and literature on program evaluation and learning and training theories. This framework is intended to evaluate training programs to improve program implementation and to develop knowledge and theories related to travel training. Therefore, the integrative theory-driven framework (Figure 2) is applied to the data collected from the Chicago Public School's Travel Training Program to assess the validity of the framework and the impacts of the program. Through this application, it is learned that the framework is useful for assessing the effectiveness and efficiency of travel training programs, program improvement and oversight. Also, it is learned that travel training intervention is likely to produce favorable outcomes for student’s post school life.

The integrative theory-driven framework for evaluating travel training consists of the three following dimensions:

1. Production and delivery of travel training

2. Outcomes and benefits

3. Moderators and mediators that influence the relationship between travel training and its outcomes

This integrative theory-driven framework provides a practical guidance on how to design and conduct evaluations of travel training programs. This section breaks down the three dimensions of the integrative theory-driven framework and its application to the Chicago Public School's Travel Training Program.

\section{Definitions.}


Assessment - Test given to disabled students to evaluate their ability to travel independently

\section{Highlights}

- $74.50 \%$ of trainees' completed training and began traveling independently

- $10 \%$ (27 out of 227) of students who passed assessment and qualified to travel independently, did not begin traveling independently

- $38.78 \%$ of the trainees' who did pass assessment cited safety as their concern

- $25 \%$ of the trainees' who passed assessment and qualified to travel independently, did not begin to travel independently because their parents did not want them to

- $91.36 \%$ of the trainees' who used 1 mode to get to school passed assessment and began traveling independently. 92.83\% of trainees' who used 1 transfer (two modes) to get to school passed assessment and began traveling independently. 95.83\% of trainees who used 2 transfers ( 3 modes) to get to school passed assessment and began traveling independently. Note: 77 participants did not indicate how many modes they used to get to school.

- Students trained 3 days or more, completed training and began traveling independently 89.18\% (173 out of 194) of the time.

- More than half, 56.52\% of trainees', who did not complete training and begin traveling independently, only trained for 1 day or less.

\section{Data Analysis}

The following section analyzes and critiques Chicago Public Schools Travel Training Program data efforts. Then the authors make recommendations to improve the program planning and evaluation of Travel Training Programs in light of the Integrative-Theory Driven framework. 
Of the 16 variables collected (Appendix B), the most important variables collected these variables:

\section{Whether the student passed eligibility assessment and began training 2. Reason why student did not pass assessment or complete training 3. Number of training days}

The following section highlights the importance of these 3 variables and their impact in relation to the effectiveness of Chicago Public Schools Travel Training Program.

\section{Effectiveness of eligibility assessment}

Based on the Chicago Public Schools travel training program guidelines (see appendix C for Chicago Public School Travel Training Guidelines), travel trainers begin with an assessment evaluate of the student's ability to travel independently, complete training, and begin traveling independently. The rationale behind this is that the assessment will provide insight into the preparedness of the student to travel independently based on multiple physical and emotional factors. The assessment will allow the trainers to impact training based on the needs of the student. The premise is that those who get trained, will be in a position to travel independently. In analyzing the data from CPS, it is revealed that $88.1 \%$ (200 out of 227) of students who passed the assessment, and completed training, began traveling independently (Figure 1). We conclude that the eligibility assessment is of high quality. 


\section{Impact of Student Assessment}

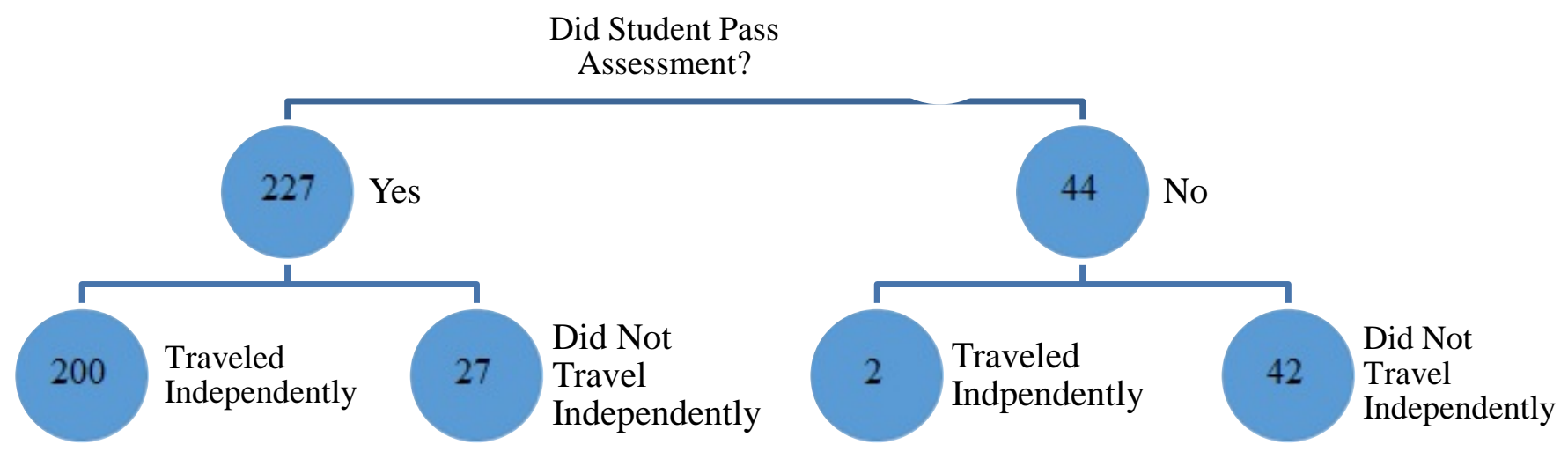

Figure 1 Impact of Assessment

\section{Independent Travel}

Anxiety and fear was the most important reason as to why students did not pass assessment, complete training and begin traveling independently (Figure 2). $80.65 \%$ of participants who did not pass assessment or complete training was due to anxiety or fear concerns (safety concerns, parent/guardian decided not to allow student to travel independently, student decided to travel independently, and health concerns were put into the category of anxiety and fear). 25\% of the trainees' who passed assessment and qualified to travel independently, did not begin to travel independently because their parents did not want them to (Figure 2). This parental and guardian behavior can negatively impact travel training program outcomes. In order to overcome this barrier, parents and guardians need to have a relationship that is based on trust and respect to produce better outcomes and benefits (Groce, 1996a, 2000; Joffee, 1996; Laurent Clerc National Deaf Education Center, 2007; Ride Connection, 2009). Clear communication among trainers, parents and students can reduce or eliminate feelings of fear or anxiety. The elimination of fear and anxiety among parents/guardians, trainees and trainers can enable a student to complete the program. As the third important variable will demonstrate, Number of Training Days (3), students are far more likely to travel independently when they complete training (figure 3). 
Reasons for NOT traveling independently

\begin{tabular}{|l|c|c|}
\hline & Student did not pass assessment & Student passed assessment \\
\hline Safety Concerns & $46 \%$ & $40 \%$ \\
\hline $\begin{array}{l}\text { Parent/guardian decided not to } \\
\text { travel independently }\end{array}$ & $23 \%$ & $26 \%$ \\
\hline $\begin{array}{l}\text { Student decided not to travel } \\
\text { independently }\end{array}$ & $9 \%$ & $11 \%$ \\
\hline Health Concerns & $6 \%$ & $6 \%$ \\
\hline Other & $16 \%$ & $17 \%$ \\
\hline
\end{tabular}

Figure 2 Reasons for not Traveling Independently

Note: 6 students listed two reasons and 1 student listed three reasons

\section{Training Days and Independent Travel Success}

The Number of Training Days for a student can indicate if a student will travel independently. Of the students who completed at least 3 days of training, 89.18\% (173 out of 194) began traveling independently (figure 3).

\section{Number of Training Days and Did Student Complete Training and Begin Traveling Independently?}

\begin{tabular}{|l|c|c|c|}
\hline \multirow{2}{*}{ Number of Training Days } & \multicolumn{2}{|c|}{$\begin{array}{c}\text { DID STUDENT COMPLETE TRAINING AND } \\
\text { BEGIN TRAVELING INDEPENDENTLY? }\end{array}$} & \multirow{2}{*}{ Total } \\
\cline { 2 - 3 } & No & Yes & 77 \\
Less than 2 days & 48 & 29 & 194 \\
3 or more days & 21 & 173 & 271 \\
\hline
\end{tabular}

Figure 3

Note: See appendix for the number of students who passed assessment and their number of training days.

More than half of trainees (56.52\%), who did not complete training and begin traveling independently, only trained for 1 day or less. $86.4 \%$ of students who did not pass assessment and complete training only trained for 1 day or less (figure 4). 


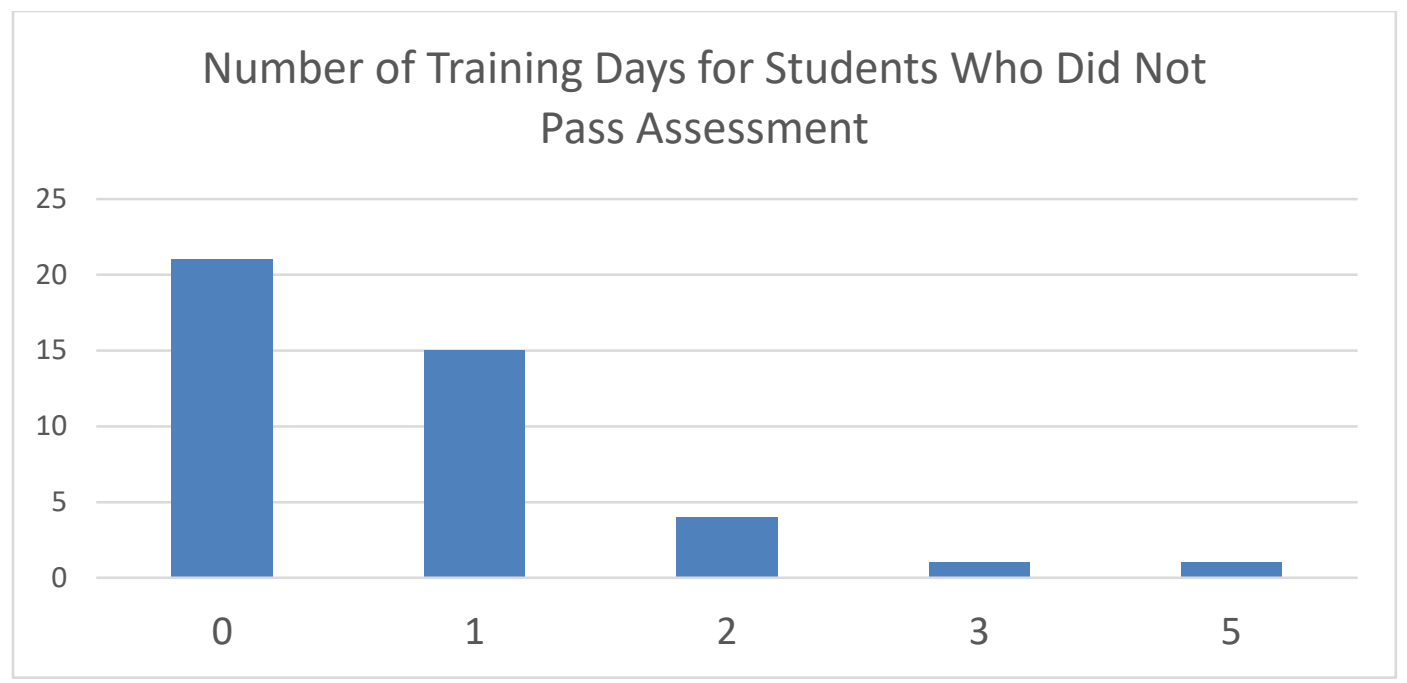

Figure 4

The numbers reflect that the Travel Training Program is effective only if students are in it for at least 3 days. This drastically improves their chances to travel independently. Nearly 90\% (173 out of 194) of students who completed at least 3 days of training, began traveling independently. Anxiety and fear concerns among parents/guardians and trainees are the primary reason as to why students do not successfully complete the travel training program. As previously indicated, $80.65 \%$ of participants who did not pass assessment or complete training was due to anxiety or fear concerns (safety concerns, parent/guardian decided not to allow student to travel independently, student decided to travel independently, and health concerns were put into the category of anxiety and fear). To produce favorable outcomes, anxiety and fear concerns can be eliminated with relationship(s) built on respect and trust. The communication among parents/guardians, trainers and students to eliminate fear and anxiety concerns is critical to the success of the Travel Training Program because $88.1 \%$ of students who complete assessment and training, began traveling independently. Therefore, the focus of the Chicago Public Schools Travel Training Program should be on trainers, parents/guardians and students to stay committed to the travel training process and complete their training because students have a drastically significant chance at traveling independently once they complete their training.

\section{Other Data Considerations}

Chicago Public Schools Travel Training Program collected 16 different variables. These data collection efforts can improve program implementation and develop knowledge and theories 
related to travel training. However, of the 16 variables collected (Appendix A), only the variables mentioned previously, (1)Whether the student passed eligibility assessment and began training, (2) Reason why student did not pass assessment or complete training, and (3) Number of training days) appeared to have an impact on the outcome of Travel Training Program. The literature review demonstrated, for example, variables such as, Number of Transfers (figure 5) or Disability type (figure 6), would affect the outcome as well, but these variables did not seemingly impact the outcome of the CPS Travel Training Program.

Modes to and from School and Whether Student Completed Training and Began Traveling Independently

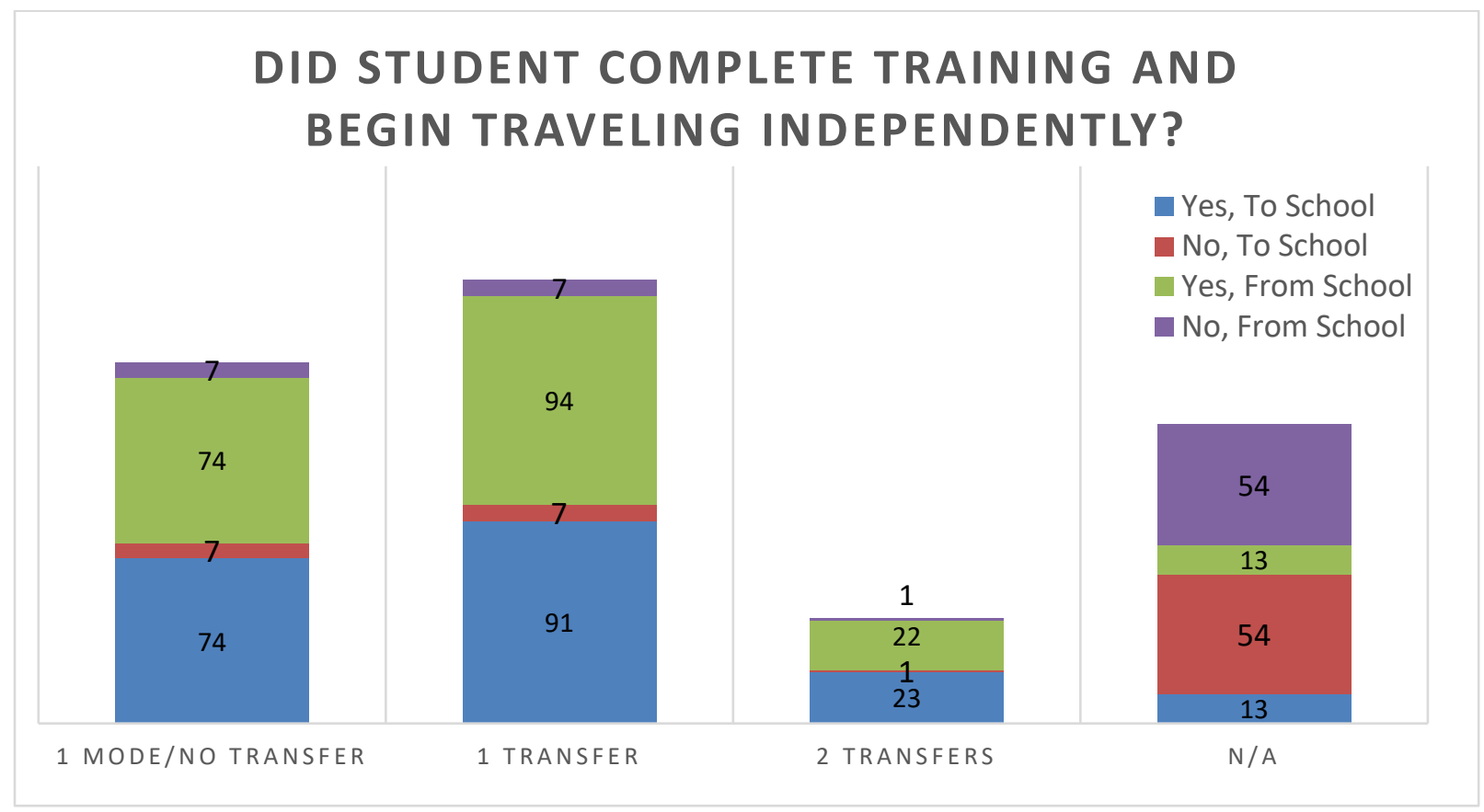

Figure 5 


\begin{tabular}{|c|c|c|c|c|c|}
\hline \multicolumn{6}{|c|}{$\begin{array}{l}\text { Primary Disability and Whether Student Completed Training and Began } \\
\text { Traveling Independently }\end{array}$} \\
\hline & & & & & \\
\hline & & & \multicolumn{2}{|c|}{$\begin{array}{c}\text { DID STUDENT } \\
\text { COMPLETE } \\
\text { TRAINING AND } \\
\text { BEGIN TRAVELING } \\
\text { INDEPENDENTLY? }\end{array}$} & \multirow[b]{2}{*}{ Total } \\
\hline & & & No & Yes & \\
\hline \multirow{4}{*}{$\begin{array}{l}\text { Primary } \\
\text { Disability }\end{array}$} & $\mathrm{HI}$ & Count & 21 & 97 & 118 \\
\hline & Disability & $\%$ of Total & $7.7 \%$ & $35.8 \%$ & $43.5 \%$ \\
\hline & LI & Count & 48 & 105 & 153 \\
\hline & Disability & $\%$ of Total & $17.7 \%$ & $38.7 \%$ & $56.5 \%$ \\
\hline \multirow[t]{2}{*}{ Total } & & Count & 69 & 202 & 271 \\
\hline & & $\%$ of Total & $25.5 \%$ & $74.5 \%$ & $100.0 \%$ \\
\hline
\end{tabular}

Figure 6

\section{Recommendations: Chicago Public Schools Data Collection Effort}

The analysis of the results of the Travel Training Program revealed certain trends and also provided insight into some factors that affect the outcomes. By comparing the results with the integrative framework, the authors have come up with recommendations (figure 5) for improving data collection. In light of the evaluation framework discussion, there are key pieces of data missing that could improve the Chicago Public Schools travel training program’s (1) production and delivery of travel training; (2) outcomes and benefits; (3) moderators and mediators that influence the relationship between travel training and its outcomes. Additional data collection should help improve scholars and practitioner's ability evaluate travel training programs.

The Chicago Public Schools Travel Training Program collected 16 variables that the authors recommend to continue to be collected (see Appendix A for list of variables). However, there are opportunities for augmenting the CPS data collection plan for evaluation. As a result of the data analysis, the authors suggest these variables be collected (figure 5). 
Data Collection Recommendations

\begin{tabular}{|l|l|}
\hline \multicolumn{1}{|c|}{ Variable } & \multicolumn{1}{|c|}{ Function } \\
\hline $\begin{array}{l}\text { Length of trainees' journey to and from } \\
\text { school }\end{array}$ & $\begin{array}{l}\text { Can be indicative to the ease of journey and } \\
\text { also may explain the travel infrastructure }\end{array}$ \\
\hline $\begin{array}{l}\text { Trainee's knowledge, usage, and } \\
\text { experience/history with public transit system } \\
\text { before training (pre- and post- evaluation) }\end{array}$ & $\begin{array}{l}\text { A standardized pre- and post-evaluation test } \\
\text { can be an indicator of the instructors' skills } \\
\text { and competencies. It can explain if students } \\
\text { underwent training when they were younger }\end{array}$ \\
\hline $\begin{array}{l}\text { Trainers' method of communication with } \\
\text { student and parents/guardian }\end{array}$ & $\begin{array}{l}\text { Overcome feelings of anxiety or fear for } \\
\text { parents and students. Builds trust. }\end{array}$ \\
\hline $\begin{array}{l}\text { Tools and aides used to train students } \\
\text { Indicates students' preference of learning } \\
\text { style }\end{array}$ \\
\hline $\begin{array}{l}\text { Trainers', trainees'and parent(s)'/guardian(s)' } \\
\text { satisfaction levels associated with travel } \\
\text { training program (pre/during/post) }\end{array}$ & $\begin{array}{l}\text { Indicates attitudes towards travel training } \\
\text { program }\end{array}$ \\
\hline Trainers' experience level with travel training & Demonstrates experience level of trainer \\
\hline $\begin{array}{l}\text { What was the student's transit mode to and } \\
\text { from school before the Travel Training } \\
\text { Program? (bus or paratransit) }\end{array}$ & $\begin{array}{l}\text { Explains context of environment and } \\
\text { collaborative process }\end{array}$ \\
\hline
\end{tabular}

Figure 7

\section{Cost Saving Analysis}

A cost benefit analysis of the Chicago Public Schools Travel Training Program was quantified to estimate savings (Figure 9 \& 10). Students would save districts $\$ 2,957,911$ in a year if they traveled independently and paid a student rate. If students pay full fare, students would save districts $\$ 2,866,740$ per year. These savings come from the yearly bus cost subtracted from the CTA student and full fare cost (Figures 8, 9, \& 10). Figure 8 details Chicago Transit Agency fare costs and Figure 9 and 10 detail the modes of transit each student chooses to get to and from, yearly school bus savings, and the cost associated with their travel.

Assumptions: The yearly school bus cost per student calculation was based on the estimated annual cost for one student riding the school bus $(\$ 7,500)$. This calculation assumes students will continue to travel independently to school for the next year and bus routes are consolidated and/or eliminated. Full fare and student fare yearly costs were made based on Chicago Transit Agency (CTA) prices (Figure 8). 


\begin{tabular}{|l|r|r|r|}
\hline $\begin{array}{l}\text { BASE/REGULAR FARES } \\
\text { (as deducted from transit value in a Ventra transit } \\
\text { account) }\end{array}$ & Full & Reduced & Student \\
\hline 'L' train fare & $\$ 2.25^{\star}$ & $\$ 1.10$ & $\$ .75$ \\
\hline Bus fare & 2.00 & 1.00 & .75 \\
\hline Transfer (up to 2 additional rides within 2 hrs) & .25 & .15 & .15 \\
\hline
\end{tabular}

Figure 8

Source: http://www.transitchicago.com/fares/

\section{Modes TO School}

\begin{tabular}{|lcllc|}
\multicolumn{1}{c}{$\begin{array}{c}\text { Travel to } \\
\text { School }\end{array}$} & Students & $\begin{array}{c}\text { Yearly school bus cost } \\
\text { per student }\end{array}$ & $\begin{array}{r}\text { CTA Full fare } \\
\text { year cost total }\end{array}$ & $\begin{array}{c}\text { CTA Student fare } \\
\text { year cost total }\end{array}$ \\
\hline 1 bus & 64 & $\$ 480,000$ & $\$ 23,040$ & $\$ 8,640$ \\
1 train & 9 & $\$ 67,500$ & $\$ 3,645$ & $\$ 1,215$ \\
1 bus 1 train & 12 & $\$ 90,000$ & $\$ 4,860$ & $\$ 1,944$ \\
2 buses & 80 & $\$ 600,000$ & $\$ 32,400$ & $\$ 12,960$ \\
2 buses 1 train & 5 & $\$ 37,500$ & $\$ 2,250$ & $\$ 945$ \\
2 trains & 1 & $\$ 7500$ & $\$ 450$ & $\$ 162$ \\
2 trains 1 bus & 2 & $\$ 1500$ & $\$ 990$ & $\$ 378$ \\
3 buses & 16 & $\$ 120,000$ & $\$ 7200$ & $\$ 3,024$ \\
N/A & 13 & $\$ 97,500$ & & $\$ 29,268$ \\
Totals & 202 & $\$ 1,501,500$ & $\$ 74,835$ & \\
\hline
\end{tabular}

Figure 9

Note: 13 students did not indicate mode of transit

\section{Modes FROM School}

\begin{tabular}{|lcllc|}
\hline $\begin{array}{c}\text { Travel from } \\
\text { School }\end{array}$ & Students & $\begin{array}{c}\text { Yearly school bus cost } \\
\text { per student }\end{array}$ & $\begin{array}{l}\text { CTA Full fare } \\
\text { year cost total }\end{array}$ & $\begin{array}{c}\text { CTA Student fare } \\
\text { year cost total }\end{array}$ \\
\hline 1 bus & 64 & $\$ 480,000$ & $\$ 23,040$ & $\$ 8,640$ \\
1 train & 9 & $\$ 67,500$ & $\$ 3,645$ & $\$ 1,215$ \\
1 bus 1 train & 9 & $\$ 67,500$ & $\$ 3,645$ & $\$ 1,458$ \\
1 train 1 bus & 3 & $\$ 22,500$ & $\$ 1,350$ & $\$ 486$ \\
2 buses & 81 & $\$ 607,500$ & $\$ 32,805$ & $\$ 13,122$ \\
2 buses 1 train & 5 & $\$ 37,500$ & $\$ 2,250$ & $\$ 945$ \\
2 trains & 1 & $\$ 7,500$ & $\$ 450$ & $\$ 162$ \\
2 trains 1 bus & 2 & $\$ 15,000$ & $\$ 990$ & $\$ 378$ \\
3 buses & 15 & $\$ 112,500$ & $\$ 6,750$ & $\$ 2835$ \\
N/A & 13 & $\$ 97,500$ & & $\$ 29,241$ \\
Totals & 202 & $\$ 1,515,000$ & $\$ 74,925$ & \\
\hline
\end{tabular}

Figure 10

Note: 13 students did not indicate mode of transit 


\section{References}

http://www.transitchicago.com/fares/

http://www.projectaction.org 


\title{
Appendix 1. An Integrative Theory-Driven Framework for Evaluating Travel Training Programs. Manuscript under Revision at Evaluation and Program Planning, Chul Hyun Park, Eric W. Welch and P. S. Sriraj, 2016
}

\begin{abstract}
Since the 1970s, travel training programs, which provide a short-term training to people with disabilities and older people to teach them independent travel skills required to use fixed-route transportation, have spread across the United States. But the authors note that currently, there is no integrative framework for evaluating the training programs, although it is crucial for improving program implementation and developing knowledge and theories related to travel training. Therefore, this research aims to build an integrative theory-driven evaluation framework of the programs on the basis of prior studies on travel training and the literature on program evaluation and learning and training theories. The framework considers (1) a wide range of key elements related to the delivery systems and outcomes of travel training; (2) diverse stakeholders that engage in designing, operating, and assessing travel training; and (3) the shortterm, intermediate, and long-term outcomes of the programs. Based on the framework, the authors develop a flexible logic model for travel training programs to help scholars and practitioners design and conduct actual evaluation studies. Thus, this research is expected to make theoretical and practical contributions to theory-driven program evaluation and travel training programs.
\end{abstract}

Keywords: travel training; program evaluation; theory-driven evaluation; public transit; mobility for people with disabilities and older people 


\section{Introduction}

All levels of government provide a wide range of public programs and services, including human and social services, economic development, public research and development (R\&D) investment, public education, and environmental protection. These programs aim to prevent social problems and meet unmet social needs. In the dynamic policy process, program evaluation is "the conduct of systematic inquiry that describes and explains the policies' and programs’ operations, effects, justifications, and social implications” (Mark, Henry, \& Julnes, 2000, p. 3). The ultimate aim of program evaluation is to assist decision-makers, public agencies, the public, and relevant stakeholders to better make sense of social problems and design, implement, and oversee public programs and services (Mark et al., 2000).

In this study the authors are interested in evaluating one type of non-standardized human and social program that is created and carried out at the local level: travel training for people with disabilities or older people. Unlike federal governmental programs with rigid regulations and detailed practical guides (e.g., Head Start to provide early childhood education to children in poor or low-income families), there is high variability in program context, program content, delivery system, and outcome. Moreover, the authors note that over the past three decades, a wide range of actors from the nonprofit and for-profit sectors have engaged in designing and implementing public programs and services, particularly in the field of human and social services, as public agencies have introduced a variety of collaborative arrangements across the sectors to deliver public programs and services more effectively and efficiently.

The authors contend that theory-driven evaluation can be useful and appropriate for evaluating these non-standardized human and social programs in which multiple actors are involved (Chen \& Rossi, 1980; Chen, 1990; Walshe, 2007). Theory-driven evaluation is "any 
evaluation strategy or approach that explicitly integrates and uses stakeholder, social science, some combination of, or other types of theories in conceptualizing, designing, conducting, interpreting, and applying an evaluation" (Coryn et al., 2011, p. 201). Such an approach to evaluation "first attempts to map out the programme theory lying behind the intervention and then design a research evaluation to test out that theory" (Walshe, 2007, p. 58). Theory-driven evaluation aims to not only determine whether a program works, but also understand when, how, and why a program works. In other words, this approach to evaluation seeks to unpack "the complex relationship between [program] context, content, application and outcomes, and to develop a necessarily contingent and situational understanding of effectiveness [and efficiency]" (Walshe, 2007, p. 58). In particular, Evaluation and Program Planning has contributed to the theoretical and practical development of theory-driven evaluation by publishing many studies over the last three decades based on this approach in diverse contexts, such as mental health care systems and higher education (e.g., Bickman, 1989, 1996; Brousselle \& Champagne, 2011; Chen \& Rossi, 1980, 1989; Donaldson \& Gooler, 2003; Lipsey \& Pollard, 1989; Nesman, Batsche, \& Hernandez, 2007)

Among non-standardized human and social programs in which a wide range of individual and organizational actors engage, the authors focus on travel training programs which are shortterm, intensive instructional programs that teach people (students in particular) with disabilities and older people the skills required to independently and safely use fixed-route public transportation (Easter Seals Project ACTION, 2004; Groce, 1996b). Over the past four decades, travel training programs have spread across the United States due to a variety of benefits for trainees, parents, guardians, and caregivers, public transportation agencies, schools, and the community at large (AECOM, 2011; Baginski, 2008; Ride Connection, 2009; K. Wolf-Branigin 
\& Wolf-Branigin, 2010). While most prior studies on travel training have focused on the development of practical guides, some scholars and practitioners have sought to develop evaluation models or tools and conduct evaluation studies to examine the effectiveness and efficiency of the programs. But the authors note that currently, an integrative theory-driven evaluation framework of travel training programs does not exist. Thus, information and knowledge about the programs and the methods for evaluation are fragmented. In this research, the authors review prior studies on travel training (both practical guides and evaluation research) and the literature on learning and training to create an integrative theory-driven evaluation framework for travel training programs. This framework is aimed at contributing to the integration of prior knowledge about the programs, but also provide theoretically informed, practical guidance on how to design and conduct evaluations of the programs.

This framework includes three key dimensions: the production and delivery of travel training (types of training providers, instructors’ skills, and training models and contents); outcomes (benefits for trainees, parents, guardians, and caregivers, schools, training providers, public transportation authorities, and the community at large); and moderators and mediators that influence the relationship between travel training and its outcomes (travel infrastructure, trainees’ characteristics, involvement of parents, guardians, and caregivers, and collaboration and partnership within the government and across the public, nonprofit, and private sectors). Also, based on the framework, the authors suggest a comprehensive logic model of travel training consisting of resources, activities, outputs, and short-term, intermediate, and long-term outcomes. The framework and the logic model can be useful for evaluators and practitioners to assess the efficiency and effectiveness of travel training (summative evaluation), to modify and improve travel training (formative evaluation), and to conduct ongoing oversight. 
The remainder of the article illustrates travel training programs in terms of the contents, phases (or process) and outcomes of travel training. Then, prior evaluation studies on travel training are reviewed and assessed. After that, the paper presents a theory-driven framework for evaluating travel training and a logic model of travel training to help evaluators and practitioners actually design and conduct evaluation research. Lastly, the authors provide theoretical and practical implications for evaluating travel training programs.

\section{Travel Training Programs (TTPs)}

According to the American Public Transportation Association (APTA), in 2013 Americans took approximately eleven billion trips (thirty five million times each weekday) on public transportation, including buses, light rails, subways, and commuter trains (Neff \& Dickens, 2013). Public transportation provides individuals with opportunities to travel from and to their homes, schools, workplaces, restaurants, hospitals, shopping malls, and other places. But, some groups of Americans such as people with disabilities and older people have difficulty using public transportation, thus these groups of people are likely to be excluded from the conveniences of public transportation. People with disabilities and older people are often in need of assistance in using the public transportation system because of the complexity in understanding the schedule (cognitive), accessing the system (physical), and transferring within the system (spatial and temporal). These factors lead to decreased mobility for these groups of people. Such mobility issues are also associated with the inequality of opportunity for work, leisure, education, and socialization. In an effort to address such social problems related to the mobility and inequality issues, several federal laws and regulations have been enacted in the United States. Importantly, under the Americans with Disabilities Act of 1990 (ADA), any 
person with a disability has a right to access to transportation. Also, the Individuals with Disabilities Education Act (IDEA) requires public schools to provide transportation services for youth with disabilities to help them prepare for the transition from school to adult life. Similar laws and policies exist in other developed countries. For examples, the United Kingdom's Equality Act 2010 is aimed at supporting and "promot[ing] equality for disabled people, which includes mobility as a key component” (AECOM, 2011, p. 17). Also, the United Kingdom's Education and Inspections Act 2006 requires local education authorities (LEAs) to assess the transport needs of students with disabilities and provide suitable transport arrangements to these students for free.

As a result of those laws and regulations, paratransit, which is a type of on-demand special public transportation services, becomes the main mode of transportation for people with disabilities who have difficulty using the public transportation system. But paratransit services have several disadvantages. First, to use the services, a passenger is required to reserve a ride in advance (e.g., one day before his/her use). Hence, this reservation-only system is likely to be inappropriate in an unforeseen or unplanned situation. Moreover, from a perspective of transportation management, a paratransit trip is very costly for local transportation authorities, compared to a fixed-route trip (Balog, 1997; Maryland Transit Association, 2007).

In addition to people with disabilities, older people are likely to have mobility issues, when this group of people begins to reduce driving. “The prevalence of driving [declines] sharply with increasing age, ranging from $88 \%$ of men [and $70 \%$ of women] in their early 70 s to" $55 \%$ of men and $20 \%$ women aged 85 years or older (Foley et al., 2002, p. 1285). Older people’s driving cessation tends to hinder access to vital services and social and other activities 
and to cause social isolation and depression, thus leading to overall a poorer quality of life (Babka et al., 2009; Musselwhite, 2010).

As an alternative for improving transportation accessibility of people with disabilities and older people and for reducing the burden on paratransit services, travel training programs were developed in the 1970s and have spread across the United States as well as other developed countries such as the United Kingdom and Australia over the last four decades. Travel training programs provide short-term, comprehensive, and intensive training sessions designed to teach trainees how to use fixed-route public transportation safely and independently (Groce, 1996b). Training program providers include public schools, school districts, local public transportation authorities, human and social service agencies, for-profit organizations, and nonprofit organizations advocating for people with disabilities or older people.

Target groups of travel training include people with disabilities of all ages and older people. In the United States, approximately 57 million people had disabilities in 2010 (Brault, 2012). This study pays particular attention to people with disabilities aged 15 and older (approximately 51 million), because this group of people is eligible to receive travel training programs and to travel independently. But it also addresses older people, defined as adults aged 65 years or older. In 2010, the overall population 65 years and over numbered 40.3 million in the United States (13\% of the total population) (Werner, 2011). Among these target groups, it is necessary to differentiate older people from people with disabilities. According to Babka and colleagues (2009), most of older people aged between 65 and 84 years who attend travel training tend to have relatively good health status and are less likely to suffer the cognitive, physical, spatial, and temporal issues that people with disabilities do. Older people aged over 80 years may have serious cognitive and physical problems such as memory impairment or difficulty in 
activities of daily living (ADLs). In such cases, those groups of people are categorized as people with disabilities. Interestingly, current older drivers are more likely to attend travel training than non-drivers (Babka et al., 2009). Older drivers consider public transportation as a future transportation option. Actually, older people "who gradually reduce driving and replace it with alternative transport and travel cope better when finally giving-up the car” (Musselwhite, 2010, p. 2).

"People with different types of disabilities have profoundly different training needs" and travel issues (Balog, 1997, p. 37). Particularly, hearing and vision impairments need to be noted. In 2010, there were 16 million people with vision and hearing impairments in the United States (Brault, 2012). These groups of people often have difficulty communicating with a bus driver and indicating that their bus stop is coming up (Balog, 1997). Blind or visually impaired individuals are specifically concerned about gathering information for travel regarding routes, timetables, fares, displayed signs, and maps. Therefore, when developing travel training service programs for people with different types of disabilities, it is crucial to "allow enough variation to address any possible needs of people with disabilities” (Balog, 1997, p. 37).

To receive travel training services, typically, older people or their caregivers and individuals with disabilities or their parents and guardians first need to apply for the training program. The individuals are also referred by schools, human and social service agencies and other public programs. Following the application and referral process, the individuals' needs, skills and travel routes are thoroughly assessed by travel training instructors to determine the eligibility for travel training. If travel training is recommended as a result of the preassessments, personalized travel training plans are developed in collaboration among the instructors, parents, guardians, and caregivers, and physical or occupational therapists. Then, 
travel training instructors carry out their training sessions. In general, travel training consists of in-class and on-site training sessions. In class, the trainees learn basic information and knowledge required to use fixed-route transportation with regard to appropriate travel behavior, communication skills, how to read traffic signs and maps, how to gain traffic information and how to purchase and pay fares. On-site training, carried out in the real environment, teaches the trainees how to travel to and from home, school, the workplace and other locations (AECOM, 2011). Instructors typically write a daily progress report to keep a record of the trainees’ improvement or problems that need to be addressed. Finally, instructors evaluate whether their trainees are able to travel independently and safely by using fixed-route transportation. If a trainee has acquired requisite knowledge and skills for independent and safe travel, he or she is recommended to travel alone. But if a trainee is not ready for independent and safe travel, the instructors discuss with the trainee and parents, guardians, or caregivers with regard to the issues that need to be resolved in the training process, the re-application of travel training or the use of paratransit services as an alternative to fixed-route transportation.

Travel training programs are expected to create a variety of benefits for the trainees, their parents, guardians, and caregivers, public transportation agencies, and the community at large (AECOM, 2011; Baginski, 2008; Ride Connection, 2009; K. Wolf-Branigin \& Wolf-Branigin, 2010). Trainees can learn how to use fixed-route public transportation independently which (1) increases self-confidence, self-advocacy, and independence; (2) provides opportunities to attend schools for post-secondary education, get a job, or enjoy various social activities; and (3) improves health status, well-being, and quality of life. "The main benefit to parents...[,guardians, and caregivers] is a reduction in care responsibilities, enabling greater participation in employment, education and leisure activities” (AECOM, 2011, p. vi). 
Moreover, as trained individuals switch to fixed-route public transportation, local transportation agencies can reduce the operating costs of paratransit services. The benefits to the community at large include "more people in employment or education...[and] increased use of sustainable travel modes” (AECOM, 2011, p. vii).

\section{Literature Review: Prior Evaluation Studies on Travel Training Programs}

Over the last four decades, travel training programs have been studied in several western developed countries, particularly in the United States (e.g., Easter Seals Project ACTION ${ }^{1}$ ) and the United Kingdom (e.g., Bradford Travel Training Unit ${ }^{2}$ ). Most prior studies on travel training have focused on the development of practical guides to designing and operating the training programs (Easter Seals Project ACTION, 2004, 2013a; Mccarthy, Shannon, \& Wolf-Branigin, 2010; Ride Connection, 2009). But some scholars and practitioners have developed evaluation models for travel training programs and applied these models to the diverse contexts of travel training (e.g., older people who give up driving and students with physical or learning disabilities) to assess the effectiveness and efficiency of the training programs (Bridger, 2011; Neef, Iwata, \& Page, 1978; Stevens, Battellino, \& Pedler, 2013; K. Wolf-Branigin \& WolfBranigin, 2010).

\footnotetext{
${ }^{1}$ http://www.projectaction.org/

${ }^{2}$ http://www.bradfordtraveltraining.co.uk/
} 
Insert Table 1 about here

Several scholars and practitioners sought to develop travel training evaluation models for assessing impacts, and cost and benefits. AECOM (2011) provided a comprehensive list of potential indicators to measure the outputs, benefits, and costs of travel training by taking into account diverse stakeholders related to operating the training programs (i.e. the trainees, parents, guardians, and caregivers, public agencies, and the community at large). Laurent Clerc National Deaf Education Center (2007) developed pre- and post-assessment tools to examine the impacts of travel training on the trainees' knowledge of fixed-route transportation and feeling about traveling independently. Moreover, based on focus group methodology with an expert panel, K. Wolf-Branigin and M. Wolf-Branigin (2010) created the three different cost-benefit analysis models for travel training programs by taking into account the costs and benefits of the trainees, public transportation agencies, and the community as a whole. To estimate the costs of delivering travel training services more accurately, K. Wolf-Branigin and M. Wolf-Branigin also developed a comprehensive, detailed monthly budget worksheet including personnel, finance, occupancy, equipment, and supply costs (Easter Seals Project ACTION, 2012). SQW Consulting, a United Kingdom-based consulting firm in the field of economic and social development, created an independent travel training cost-benefit analysis model providing userfriendly, excel-based templates to help scholars and practitioners easily calculate the costs, benefits, and rates of return of travel training. The SQW model developed to evaluate travel training for students with disabilities took into account the following benefits: (1) financial savings for local transportation agencies; (2) the environmental benefit (i.e. the reduction in 
$\mathrm{CO}^{2}$ ); and (3) the wider benefits for parents or guardians. In addition, one-off set up costs, operating costs and public transport fares are considered as the costs of delivering the training programs.

Furthermore, some scholars and practitioners have conducted evaluation studies to assess the effectiveness (i.e. impacts) and efficiency (i.e. cost-benefit ratio or net-benefits) of travel training programs by applying evaluation models developed to the actual travel training contexts. Babka and colleagues examined the impacts of travel training on older people' knowledge of how to use local public transit independently by employing pre- and post-training surveys (Babka et al., 2009). Baginski (2008) assessed the impacts of travel training on the perceptions of students with disabilities towards independence, self-confidence, self-advocacy in a suburban school setting by employing pre- and post-training surveys and qualitative interview methods. Bridger (2011) identified the direct and indirect impacts of travel training on the trainees (i.e. students with disabilities), their parents and guardians, and the community at large by using qualitative interviews. Neef and colleagues examined the relative effectiveness of two approaches to travel training for students with disabilities (i.e. classroom instruction and on-site training) by using a multiple baseline across subjects (Neef et al., 1978). Moreover, Welsh Local Government Association, Welsh Assembly Government, and the City of Cardiff Council (2011) conducted interview-based qualitative research on the outcomes of a pilot travel training program for students with disabilities by taking into consideration (1) a variety of the outcomes of the training program (i.e. benefits for the trainees, schools, and parents and environmental benefits); and (2) diverse stakeholders involved in the training program. According to the prior impact studies mentioned above, travel training programs made a variety of positive impacts on the trainees (e.g., the increase in knowledge on how to use fixed-route transportation, independence, 
self-esteem, and educational opportunities), parents, guardians, and caregivers (e.g., the reduction in care responsibilities), other stakeholders, such as schools and local transportation agencies (e.g., administrative and financial cost-savings), and the wider community (e.g., the reduction in $\mathrm{CO}^{2}$ ).

In addition to the impact studies, several scholars and practitioners conducted cost-benefit analyses of travel training. Neef and colleagues (1978) examined the relative efficiency of two different travel training models. They found that classroom training was more cost-efficient than onsite training. Bridger (2011) also estimated cost savings made through travel training "by comparing the cost of a travel training program and bus...[and] train fares with the cost of providing supported transport” for students with disabilities (p. 22). According to the Welsh Local Government Association et al. (2011), travel training resulted inimmdeiate cost savings as well as longer term savings over three and a half years. Moreover, Stevens and colleagues took into account the following benefits of travel training: (1) social benefits (i.e. the reduction in social isolation); (2) economic benefits (i.e. the trainees' increased income and consumption); (3) travel benefits (i.e. cost savings to the trainees and government from switching to public transport); (4) benefits for parents, guardians, and caregivers (i.e. the increase in leisure time); and (5) environmental benefits (i.e. the reduction in $\mathrm{CO}^{2}$ ). Travel training resulted in estimated financial benefits of $\$ 261,000$ (Stevens et al., 2013, p. 11). The authors also estimated a benefitcost ratio of approximately 3.40:1, which indicates each dollar spent for travel training programs results in a total benefit of $\$ 3.40$. From the perspective of local transportation agencies, $\mathrm{K}$. Wolf-Branigin and colleagues applied a previously developed cost-benefit analysis model (K. Wolf-Branigin \& Wolf-Branigin, 2010) to three different travel training programs (K. WolfBranigin, Wolf-Branigin, Culver, \& Welch, 2012). Findings showed that the benefit-cost ratios 
of the three travel training programs were approximately 1.50:1, 2.00:1, and 4.00:1. In other words, for each dollar spent for operating travel training programs, the local public transportation agencies saved or diverted $\$ 1.50, \$ 2.00$, and $\$ 4.00$ in personnel, equipment and supplies, respectively. In sum, prior cost-benefit analyses on travel training showed various benefits for the trainees, parents, guardians, and caregivers, local public transportation authorities and the community at large and demonstrated that these benefits were much greater than the costs of operating travel training.

\section{Assessment of the Existing Travel Training Evaluation Studies}

Prior evaluation studies on travel training have focused on (1) developing evaluation models (or tools) for impact studies and cost-benefit analysis and (2) applying the evaluation models (or tools) to the actual program settings to determine the effectiveness and efficiency of travel training. These previous studies provide important information and knowledge of key stakeholders, diverse training models and approaches, and the outcomes (or benefits) and costs of travel training. However, the authors note that most of the prior evaluation studies have focused narrowly on specific stakeholders (e.g., the trainees or their parents or guardians), outputs or outcomes (e.g., the increase in the trainees' knowledge of how to use fixed-route public transportation) and costs of travel training programs (see Table 2). Thus, these prior studies provide partial or fragmented understanding of travel training programs.

Several scholars and practitioners have tried to build relatively comprehensive models for the impact studies and cost-benefit analysis of travel training (AECOM, 2011; Stevens et al., 2013; K. Wolf-Branigin \& Wolf-Branigin, 2010). But, importantly, these models are incomplete because they do not consider (1) a wide range of outcomes (particularly, non-monetized benefits) for respective stakeholders over time (i.e. intermediate and long-term benefits) and (2) various 
mediators, moderators, or confounders in the relationship between travel training and its impacts (e.g., the trainees’ motivation and learning styles and the difference in training models and approaches).

In response, the next section suggests an integrative theory-driven framework for evaluating travel training programs. To build the theory-driven evaluation framework, we take into account (1) the prior studies on travel training (both practical guides and evaluation studies), (2) human resources training evaluation models, and (3) learning and training theories (See Figure 1).

Insert Table 2 and Figure 1 about here

\section{Building an Integrative Theory-Driven Framework for Evaluating Travel Training}

An integrative theory-driven framework for evaluating travel training consists of the three following dimensions: (1) the production and delivery of travel training; (2) outcomes and benefits; (3) moderators and mediators that influence the relationship between travel training and its outcomes. Figure 2 provides a visual description about the functional aspects of the theorydriven evaluation framework.

\section{Production and Delivery of Travel Training Programs}

The first dimension concerns how travel training services are produced and delivered to the trainees. Travel training providers perform a variety of activities including recruitment, application processing and referral, development of training models and instructional materials, 
classroom and onsite travel instruction and assessment. They also manage financial and human resources for operating travel training programs (e.g., applying for federal government grants and training instructors and administrative staff). As target groups, aims, training contents, the types of providers, training models and approaches, and funding resources vary widely, it is not reasonable to assume that all programs provide the same types of services (Halcrow Group Limited, 2005). This study focuses on three levels of factors related to the performance of the training providers and ultimately the service quantity and quality: (1) organization-level factors; (2) individual-level factors; and (3) training-related factors.

Organization-level factors. At the organization-level, the literature distinguishes among types of training providers, approaches to travel training, and financial sustainability. Travel training is provided by a variety of nonprofit, private and public sector organizations, including schools and school districts, transit agencies and human and social service agencies (AECOM, 2011; Easter Seals Project ACTION, 2013b; Groce, 1996b). Three approaches to travel training are most prominent in the literature: in-house training, contracting-out, and a combination of inhouse and contracted training services. According to M. Wolf-Branigin and K. Wolf-Branigin (2008), in the United States approximately 60\% of travel training services are in-house training, while $30 \%$ of the training services are contracted out to nonprofit or for-profit organizations and $10 \%$ of the training services are operated by a combination of in-house and contracted services. Finally, travel training programs in the United States are funded by (1) federal sources (e.g., Job Access Reverse Commute program funds ${ }^{3}$ and Urbanized Area Formula program funds ${ }^{4}$ ) and (2) non-federal sources (e.g., local property taxes, sales taxes, state vocational rehabilitation,

\footnotetext{
${ }^{3}$ http://www.fta.dot.gov/grants/13093_3550.html

${ }^{4}$ http://www.fta.dot.gov/grants/13093_3561.html
} 
education, or transportation departments, municipal budgets, and private foundations) (M. WolfBranigin \& Wolf-Branigin, 2008). Importantly, travel training programs are likely to be financially vulnerable, because the training programs are often funded by short-term or one-off grants (Halcrow Group Limited, 2005). Stable funding contributed to advantages in recruiting capable training instructors, developing training models and materials, and ultimately providing high-quality instruction.

Individual-level factors: Instructors' skills and competencies. The individual-level travel training factors comprise instructors' skills and competencies necessary for successful training. Instructors play a key role by reviewing application materials, conducting preassessments and evaluating the transportation environment and routes (Easter Seals Project ACTION, 2004). Based on pre-assessment results, interviews of trainees and parents and caregivers, and skill observations, the instructors develop personalized travel training plans for each trainee before trainees enter the classroom or receive one-on-one trainings. Instructors assess the ability of the trainees to travel safely and independently and to write daily progress reports during the training sessions. Finally, the instructors conduct post-training evaluations to determine if the trainees have knowledge and skills required for independent and safe trip and write a final written report.

Currently, nationally accredited programs for training travel instructors and certification for travel instructors do not exist in the United States or in other countries (Easter Seals Project ACTION, 2013a; Halcrow Group Limited, 2005). However, over the past two decades, Easter Seals Project ACTION ${ }^{5}$ has researched competencies needed for travel training instructors and has classified them into two groups: professional instructors and paraprofessional instructors.

\footnotetext{
${ }^{5}$ http://www.projectaction.org/
} 
Professional instructor has academic knowledge and field experience related to physiological and psychological aspects of disabilities, sensory motor function, human growth and development, legal and ethical issues in travel training, the systems of transportation, mobility and information access devices, travel skills and techniques, environmental and risk analysis, assessment, instructional methods and strategies, and the administration and supervision of travel training (Easter Seals Project ACTION, 2004). A paraprofessional instructor performs travel training under the direction of the professional instructor. "Competencies required of the [paraprofessional] travel trainer come from most of the same domains as for the [professional] travel training instructor but are not as inclusive and do not require the same level of knowledge” (Easter Seals Project ACTION, 2004, p. 20).

Training-related factors. Training dimension of travel training includes training models, training content and training tools and materials. Training models include informational presentations, tailored travel (one-on-one) training, peer-to-peer training and combination of two or more. Informational presentations provide participants with opportunities to gain knowledge required to use fixed-route public transportation in a classroom setting. "The advantage [of informational presentations] is that information can be distributed widely, without requiring highly trained staff” (Balog, 1997, p. 7). While informational presentations do not take into consideration participants' needs, tailored travel training provides the trainees with personalized training services based on the trainees' specific travel needs, prior travel experiences, and levels of specific disabilities. Tailored training "initially commence[s] with generic skills such as general road safety and accessing public transport....The training often moves on to repetition of the route [in the actual transportation environment]" (AECOM, 2011, p. 41). After that, the trainees travel alone and are shadowed by the instructors. The tailored training model requires 
more highly trained staff than the informational presentation model. Peer-to-peer training is conducted by former trainees who use fixed-route public transportation independently and serve on a volunteer basis. While peer instructors and trainees often relate well, safety issues can arise with this training model, particularly if peer instructors are unable to effectively deal with emergency situations (Voorhees, 1996).

The contents and topics covered in travel training vary widely (Halcrow Group Limited, 2005). To use fixed-route public transportation independently and safely, trainees need to learn and demonstrate the following knowledge and skills at a minimum (Groce, 1996a, 1996b; Halcrow Group Limited, 2005; Laurent Clerc National Deaf Education Center, 2007; Ride Connection, 2009; Samberg, 1996): (1) road safety skills; (2) reading traffic signs and transit maps; (3) finding and planning the safest and most direct and convenient travel route; (4) boarding and disembarking the correct bus or subway; (5) handling unexpected situations and emergencies; (6) dealing with strangers appropriately; (7) handling money; (8) maintaining appropriate behavior; and (9) recognizing the need for assistance and requesting help from an appropriate source. The contents and topics of travel training not only need to be inclusive, but also must be modified to fit each trainee' type and severity of disability and needs (Ride Connection, 2009).

Finally, a variety of training aids and tools have been developed to improve the effectiveness of travel training and address the concerns of parents and guardians. Travel training aids include journey picture books, simplified timetables, communication cards or wallets, mobile devices and applications, and travel training software (AECOM, 2011; Davies, Stock, Holloway, \& Wehmeyer, 2010; Shopland, Lewis, Brown, \& Dattani-Pitt, 2004). Journey picture books and simplified timetable help to remind the trainees of key travel information (e.g., 
the right bus route, orientation, and when to disembark). Communication cards or wallets help the trainees allow a driver or other people know their needs and request appropriate assistance in unexpected situations.

The importance and use of mobile technology with the global positioning system (GPS) are increasing in the field of travel training. For example, WayFinder, a smartphone-based mobile program developed by AbleLink Technologies ${ }^{6}$, provides individuals with disabilities with personalized audio and visual instructions to help to successfully navigate a specific public transportation route based on their GPS location. In an experimental evaluation, Davies and colleagues found the effectiveness of WayFinder to be greater than other traditional travel support tools, such as written bus schedules and printed maps (Davies et al., 2010).

\section{Outcomes and Benefits}

Travel training programs are expected to have a wide range of positive impacts on individual trainees, parents, guardians, or caregivers, schools and school districts, training providers, local public transportation authorities, other public agencies at the three levels of government, and the community at large (AECOM, 2011; Baginski, 2008; Bridger, 2011; Halcrow Group Limited, 2005; LaGrow, Wiener, \& LaDuke, 1990; Ride Connection, 2009; Welsh Local Government Association et al., 2011). This section identifies a wide range of travel training outcomes.

Individual trainees. According to Donald Kirkpatrick’s training evaluation model (1998), training programs create the four different levels of outcomes from a perspective of

\footnotetext{
${ }^{6}$ Ablelink was founded in 1997 to provide a variety of support technologies for people with disabilities (http://www.ablelinktech.com/)
} 
trainees: (1) reaction; (2) learning; (3) behavior; and (4) results. Reaction refers to a measure of trainees' satisfaction with training. Learning is defined as the extent of trainees' increased knowledge, improved skills and changes in attitude as a result of training programs. Behavior refers to the extent to which trainees' actual behavior is changed due to training. Results refer to the final outcomes of training programs, including "increased production, improved quality, [and] decreased costs” (Kirkland, 1998, p. 106).

Applied to travel training programs, reaction outcomes include the extent of trainees' satisfaction with the respective phases of travel training (i.e. application/referral, preassessments, individualized training planning, classroom and onsite training, and post-training evaluation). Learning outcomes include changes in attitudes (or feelings) towards traveling independently and in knowledge and skills to use fixed-route public transportation. Behavior outcomes comprise increased uses of fixed-route public transportation as primary or complementary transportation and increased moderate-intensity physical activity as a result of the use of public transportation. Results consist of a variety of social, educational and financial impacts on individual trainees. Specifically, travel training expands trainees' travel options, thereby leading to enhanced mobility (Burkhardt et al., 2014b). As a result, travel training increases an opportunity to access vital services (healthcare services and public social services) and shops, increase a chance to engage in social and leisure activities, and improves trainees' independence, self-confidence, and self-esteem, thus ultimately enhancing the quality of life (i.e. economic, physical, and mental, and social well-being) (AECOM, 2011; Babka et al., 2009; Baginski, 2008; Burkhardt et al., 2014a; Musselwhite, 2010). These outcomes benefit people with disabilities and older people. In addition, regarding benefits for students with disabilities, travel training reduces behavior problems and increases an opportunity to participate in post- 
secondary education and training, and to obtain employment opportunities (AECOM, 2011; Bridger, 2011; Welsh Local Government Association et al., 2011). Regarding benefits for older people, travel training "supports aging in place, which can help to avoid or defer the costs of nursing homes in their own homes” (Burkhardt et al., 2014a, p. 13). This economic benefit is significant because the annual median cost for nursing home care ranges from $\$ 80,300$ to $\$ 91,250$ in the United States (Genworth, 2015).

Parents, guardians, and caregivers. Travel training programs help individual trainees to travel independently by using fixed-route public transportation. As a result, travel training can reduce care responsibilities of parents or guardians of students with disabilities and caregivers for older people (AECOM, 2011; Burkhardt et al., 2014b). Therefore, parents, guardians, and caregivers can spend less time addressing transportation for students with disabilities and older people. In addition, parents, guardians, and caregivers are likely to have more time and opportunities for post-secondary education and training and employment. They are also likely to have more time and opportunities for social, recreational, and leisure activities. From a longterm perspective, economic, mental, and social wellbeing of parents, guardians, and caregivers is expected to improve.

Schools and school districts. As students with disabilities use fixed-route public transportation, schools' and school districts' costs of operating school buses for trained students with disabilities may drop. Administrative and human resource costs may also decline. Furthermore, as students with disabilities become more independently mobile. They may gain self-esteem and self-confidence, which likely will have a positive impact on classroom and school climate (AECOM, 2011; Welsh Local Government Association et al., 2011). 
Travel training providers. If a travel training provider (e.g., a local public transportation authority, a nonprofit organization or a school district) operates travel training successfully, the number of individuals who apply for travel training may increase. An increase in the number of applicants and trainees is also likely to help a travel training provider obtain sustainable funding for travel training programs from public, private, and/or nonprofit sources. The successful operation of travel training may also help the providers receive positive recognition and reputation from the public and relevant government agencies.

Public transportation authorities and operators. From the perspective of public transportation authorities and operators, the financial costs of operating paratransit are much higher than those of operating fixed-route public transportation. Thus, if people with disabilities change their transportation modes from paratransit to fixed-route public transportation after finishing travel training successfully, local public transportation’ costs from paratransit can be reduced.

Other public agencies at the three levels of government. Travel training enables individual trainees (particularly, students with disabilities) to take advantage of opportunities for education and employment, thus improving their socioeconomic status (e.g., job quality and income) (AECOM, 2011; Welsh Local Government Association et al., 2011). Improved socioeconomic status may not only reduce individual trainees' reliance on social welfare benefits, but may also increase public revenues (increased taxes, such as income taxes, property taxes, and sales taxes, paid by newly employed or better employed trainees). Moreover, travel training leads to increased mobility that provides access to healthcare services and other related social services and reduces social isolation. Such benefits improve the physical and mental 
health of people with disabilities and older people, thus reducing government spending for medical services (e.g., Medicaid and Medicare) (AECOM, 2011; Musselwhite, 2010).

Community at large. Travel training programs can create social, economic, and environmental benefits for the community at large. First, trainees (both people with disabilities and older people) are able to participate in a wide range of community events by using fixedroute public transportation (e.g., art and sport events), go to community places (e.g., libraries, senior community centers, parks and recreation centers), and attend activities designed for people with disabilities and older people (K. Wolf-Branigin \& Wolf-Branigin, 2010). Such increased involvement of trainees helps build a community of diversity and improve social inclusion (Burkhardt et al., 2014b; Stanley et al., 2011). Second, increased accessibility to shopping and services and improved socioeconomic status due to mobility and integration enable trainees (both people with disabilities and older people) to participate more in the local economy, thus creating economic benefits for the community as a whole. Third, as a result of travel training, when people with disabilities and older people use fixed-route public transportation rather than paratransit, such a change in transportation modes creates environmental benefits for the community at large, such as reduced $\mathrm{CO}_{2}$ emission, due to decreased paratransit trips (Stevens et al., 2013).

\section{Moderators and Mediators that Influence the Effectiveness and Efficiency of Travel}

\section{Training Programs}

According to the literature, there are various individual, inter-organizational, and environmental factors that can influence the effectiveness (i.e. the achievement of intended outcomes) and efficiency (i.e. a positive cost-benefit ratio) of travel training programs. Most of 
these factors have been neglected in prior evaluation studies on travel training. Thus in this section, the authors illustrate the factors that need to be considered for designing and conducting impact studies and cost-benefit analyses for travel training. These factors may act as moderators, mediators, or confounders in the relationship between travel training program objectives and activities and their outcomes (or benefits).

Travel infrastructure and environment. It is more challenging to provide travel training in rural and suburban areas than in urban areas (AECOM, 2011; Baginski, 2008). Public transportation systems in rural and suburban areas "tend to offer fewer local fixed routes and less thorough geographic coverage than their urban counterparts” (Baginski, 2008, p. 11). Thus, people with disabilities and older people in rural and suburban areas are likely to have difficulty getting access to fixed-route public transportation to travel from and to their homes, schools, workplaces and other key destinations. Moreover, the absence or lack of travel infrastructure amenities in rural and suburban areas, such as sidewalks and crosswalks, creates considerable barriers that restrict opportunities for people with disabilities and older people to travel on fixedroute public transportation. Due to these challenges and barriers, travel training in rural and suburban areas is likely to be more costly and less effective than that in urban areas (AECOM, 2011). In addition to the structural differences of rural and urban areas, the length and ease of the journey which trainees take on fixed-route public transportation are important factors associated with outcomes and costs of travel training because the longer distances and complexity of the journey may make travel training ineffective and costly (AECOM, 2011; Halcrow Group Limited, 2005).

Individual trainees’ characteristics. Individual trainees’ characteristics that can potentially influence the effectiveness and efficiency of travel training programs include trainee 
age, type and severity of disability, anxiety and fear towards training, motivation and commitment to training, learning style, and prior experience with fixed-route public transportation. The age of recipients of human and social services is considered as one important variable that needs to be controlled for when determining the causal relationship between a public service and its outcomes (Bingham \& Felbinger, 2002; Groce, 1996a). This is particularly true, if travel training programs are delivered to an age-determined population (e.g., students with disabilities between the ages of fifteen and twenty one). The type and severity of disability also need to be taken into consideration in impact studies and cost-benefit analyses for travel training programs. For example, people with severe cognitive disabilities tend to require more intensive, comprehensive, and repetitious travel training than people with mild to moderate physical disabilities (Baginski, 2008; Voorhees, 1996). Thus the training for people with severe cognitive disabilities, compared to those with mild and moderate physical disabilities, is likely to take more time and require more human and financial resources. Additionally, traveling independently tends to increase anxiety about independent travel among people with disabilities and older people (Groce, 1996b). If trainees are more anxious about independent travel, training results are less likely to be effective and efficient (LaGrow et al., 1990; Musselwhite, 2010). According to the literature, the motivation of people with disabilities and older people for travel training is strongly associated with training results (Ride Connection, 2009; Welsh Local Government Association et al., 2011). If trainees are highly motivated to travel independently, they are more likely to actively participate in travel training programs. Higher motivation leads to better training results and lower costs of implementation. Therefore, trainees' motivation for training must be acknowledged when assessing the effectiveness and efficiency of travel training programs. Also, the learning style of people with disabilities and older people can influence the 
relationship between travel training and outcomes (Ride Connection, 2009). According to the literature on training and education, respective learners have different learning styles that refer to learners' habitual or preferred way of acquiring and processing new information and knowledge (James \& Gardner, 1995). For example, some people prefer visual learning (i.e. through seeing), while others prefer auditory learning (i.e. through hearing) or kinesthetic learning (i.e. through doing) (Barbe, Swassing, \& Milone, 1979). If travel training instructors do not identify trainees' learning styles and reflect their learning styles in travel training, training results may be ineffective due to a mismatch between training and learning styles, rather than training itself. Last, evaluators need to consider trainees' prior experience using public transportation to assess the effectiveness and efficiency of travel training programs (Ride Connection, 2009). People with disabilities or older people who had significant prior experience using fixed-route public are more likely to complete the training successfully than someone who did not use public transportation prior to travel training.

Behavior and involvement of parents, guardians, and caregivers. Parents and guardians of students with disabilities and caregivers for older people can influence positively or negatively the relationship between travel training programs and outcomes. According to the literature, overprotective behavior of parents, guardians, and caregivers and their resistance to and anxiety about travel training tend to negatively impact the effectiveness and efficiency of travel training programs (AECOM, 2011; Groce, 1996b; Halcrow Group Limited, 2005; LaGrow et al., 1990). When the relationships between travel training providers (training instructors) and parents, guardians, and caregivers are based on mutual trust and respect, travel training tends to produce better outcomes and benefits (Groce, 1996a, 2000; Joffee, 1996; Laurent Clerc National Deaf Education Center, 2007; Ride Connection, 2009). Training providers first need to involve 
parents, guardians, and caregivers in conducting initial screening assessments and in developing individualized travel instruction (Laurent Clerc National Deaf Education Center, 2007). Training providers (and training instructors) need to constantly (daily) communicate with parents, guardians, and caregivers in person, by telephone, or via email to inform them of activities and progress (Groce, 1996a, 2000; Ride Connection, 2009). Such efforts help to lessen resistance to and anxiety about travel training and build trust.

\section{Collaboration and partnership among public, nonprofit and for-profit}

organizations. Most travel training programs are produced and delivered by a variety of collaborations within local, state, and/or federal governments and broader partnerships among the public, nonprofit, and private sectors. Key travel training stakeholders include public transportation departments and authorities, public transportation operators, social service departments and agencies, school districts, police departments, voluntary and nonprofit organizations, and related professionals (e.g., occupational, physical, and language therapists) (Balog, 1997; Easter Seals Project ACTION, 2004; Joffee, 1996). The types of collaborations and partnerships for travel training programs vary widely and range from contracting-out of the training program to loosely interconnected networks. It is through various collaborations and partnerships that resources (e.g., grants, expertise, and volunteers) are mobilized to provide travel training programs (AECOM, 2011; Easter Seals Project ACTION, 2004; Halcrow Group Limited, 2005; Joffee, 1996).

From the perspective of collaborative public management (Agranoff \& McGuire, 2003; Agranoff, 2012) and collaborative governance (Ansell \& Gash, 2008; Emerson, Nabatchi, \& Balogh, 2012), the collaborative context and process aid in understanding cross-sector approaches to travel training programs. The context and environment include resource 
conditions, program legal frameworks, prior history of collaboration and network connectedness. The collaborative process is characterized by communication and deliberation, mutual trust, shared understanding, procedural/institutional arrangements and leadership.

\section{A Logic Model for Travel Training Programs}

In this section the authors suggest a logic model for travel training programs to help scholars and practitioners design and conduct evaluations of the programs (See Table 3). Logic models are visual roadmaps to intended goals of a program. "[L]ogic models can be defined generally as flow charts that display a sequence of logical steps in program implementation and the achievement of desired outcomes” (Cooksy, Gill, \& Kelly, 2001, p. 120). Over the past decades, logic models have been used by many evaluators in various contexts (Helitzer et al., 2010; Kaplan \& Garrett, 2005; McLaughlin \& Jordan, 1999; Millar, Simeone, \& Carnevale, 2001). The elements of a logic model include resources (inputs), activities, outputs, and shortterm, intermediate, and long-term outcomes. Resources include human and financial inputs coming from stakeholders (e.g., individuals, organizations, partnerships, and the community at large). Activities are specific action steps related to the production and delivery of a program. Outputs are the goods and services that specific activities produce. Outcomes are multiple, sequential “changes or benefits resulting from activities and outputs” (McLaughlin \& Jordan, 1999, p. 66). Logic models display short-term, intermediate, and long-term outcomes. "Short term is often [considered to be] 1 through 3 years, [and] intermediate-term outcomes 4 through 6 years. Long-term outcomes might be achieved in 7 through 10 years” (Knowlton \& Phillips, 2009, p. 37). To some extent, the time intervals are relative and depend on various characteristics of a program (e.g., the size, scope, or period of a program). Logic models can be 
used for summative evaluation to determine the effectiveness and efficiency of a program, but also for formative evaluation to improve program implementation.

To create a logic model for travel training programs, the authors reorganized the theorydriven evaluation framework developed in this paper by categorizing a wide range of the elements of the framework into resources, activities, outputs and outcomes. This logic model includes more detailed information and knowledge about the respective phases of travel training programs. The logic model takes into account a variety of stakeholders: individual trainees, parents, guardians and caregivers, schools and school districts, training program providers, public transportation authorities, other public agencies at the three levels of government, collaborations and partnerships, and the community at large. The logic model also considers short-term (1 through 3 years), intermediate (4 through 6 years), and long-term (7 through 10 years) outcomes. It can be used for not only designing and conducting program evaluation, but also program planning and implementation (Knowlton \& Phillips, 2009).

The logic model consists of a wide range of factors related to travel training. How can these factors be prioritized in actual evaluations? To prioritize these factors, evaluators first need to figure out key characteristics of the production and delivery of travel training, such as the types of travel training providers (public agencies, nonprofit organizations, or for-profit organizations), approaches to travel training (in-house or contracting-out training), and training models (informational presentation, one-on-one training, or peer-to-peer training). These key characteristics help evaluators focus on more important factors in specific evaluation contexts regarding resources, activities, and outputs in the logic model. For example, if an evaluator assesses an in-house travel training program in which a local public agency provides training services on its own, the evaluator would not need to pay attention to factors related to 
collaboration and partnership across the public, nonprofit, and for-profit sectors in the logic model.

In addition, the key aims of specific travel training programs need to be considered to prioritize a variety of factors in the logic model. In fact, travel training programs have different aims in diverse contexts. For instance, local public transportation authorities that offer travel training aim mostly to reduce the costs of operating paratransit services. School districts offering travel training intend to help students with disabilities prepare for the transition from school to adult life. A nonprofit organization advocating for older people offer travel training to support aging in place. Thus, evaluators need to take into account a key aim(s) or goal(s) of a specific travel training program, because the key aim(s) helps evaluators determine the main outcomes of travel training (i.e. which benefits for whom) and focus on primary stakeholders (e.g., specific target groups of travel training, public transportation authorities, and/or school districts) among many outcomes and stakeholders in the logic model. For instance, if an evaluator assesses a travel training program for older people, the evaluator likely focuses on economic or social benefits for older people (e.g., reduced costs of nursing homes) and related stakeholders (e.g., senior community centers and nonprofit organizations for older people), rather than benefits for students with disabilities (e.g., increased access to secondary education and training) and related stakeholders, such as school districts. Then, in consultation with primary stakeholders, evaluators need to choose outcome timelines (short-term, intermediate, and/or long-term). For example, if short-term benefits resulting from travel training are considered to be key outcomes of interest, evaluators may focus on changes in trainee attitude towards traveling independently and increased knowledge and skills to use fixed-route public transportation, rather than improved economic opportunities, benefits and quality of life from a long-term perspective. 
Evaluators also need to consider how data to support respective factors in the logic model can be collected. Existing cost-benefit analysis models for travel training that have been developed over the past years are a good starting point for evaluators to design and conduct their own cost-benefit analyses (Easter Seals Project ACTION, 2012; SQW, 2009; Stevens et al., 2013). For example, from the perspective of travel training providers, K. Wolf-Branigin and M. Wolf-Branigin developed a detailed list of the costs of operating travel training programs, including personnel costs (e.g., trainer wages, payroll taxes, and continuing education costs), occupancy costs (e.g., rent/lease payments and utilities), and the costs of equipment and supplies (e.g., installation and repair of equipment and office supplies) (Easter Seals Project ACTION, 2012; K. Wolf-Branigin \& Wolf-Branigin, 2010). They also suggested a list of monetized benefits for individual trainees (trainee income prior to travel training and after finishing travel training), public transportation authorities (cost avoidance resulting from the use of fixed-route public transportation instead of paratransit services), and the community at large (dollars spent by trainees due to increased mobility). Other scholars and practitioners developed similar costbenefit analysis models (SQW, 2009; Stevens et al., 2013). These models complement one another and are integrated into the logic model developed in this study. Hence, existing costbenefit analysis models can be used for collecting data to measure factors of the logic model. Also, travel training providers (particularly, public agencies) usually keep records of expenses and activities related to travel training. Some local public transportation authorities track tripmaking behavior of trainees during and after travel training by using electronic fare media. Such expense, activity and trip-making data can be useful for measuring factors of the logic model. Additionally, for evaluators to design and conduct impact studies that determine the effectiveness of travel training, data to support factors of the logic model can be collected from 
interviews, assessments, and surveys before, during and after travel training. For the past years, several pre- and post-interviews, assessments and surveys for travel training have been developed (e.g., Babka et al., 2009; Baginski, 2008; Laurent Clerc National Deaf Education Center, 2007). These instruments are useful for collecting data to support factors of the logic model. "To accurately measure the changes that travel training can produce, it is important to have detailed records of how trainees traveled before their training, such as how many trips they took on which modes, how much those trips cost, and desired trips that they could not take” (Burkhardt et al., 2014a, p. 31). Also, after training is completed, many travel training providers conduct follow-up surveys via telephone or mail to document training impacts and results. Evaluators can use such survey data to conduct impact studies of travel training.

\section{Implications and Conclusions}

In this study, the authors aimed to build an integrative theory-driven framework for evaluating travel training programs on the basis of the findings from the travel training literature, evaluation research on human resources training, and learning and training theories. The framework consists of three main dimensions including the production and delivery of travel training, outcomes and benefits, and moderators and mediators that influence the relationship between travel training and its outcomes and benefits. Also, we developed a logic model for evaluating the programs for theoretical and practical purposes. We contend that the framework and the logic model can contribute to achieving the three key purposes of program evaluation (Mark et al., 2000; Rossi, Freeman, \& Lipsey, 1999; Ruegg \& Feller, 2003): (1) the assessment of the merit and worth of a program; (2) program and organizational improvement; and (3) oversight and compliance. First, the framework and the logic model provide the accumulated 
information and knowledge about key stakeholders, service production and delivery methods, and the actual or potential outcomes of travel training programs. Therefore, the framework and the logic model can be useful for designing and implementing summative evaluation to determine the merit and worth of travel training programs, because it helps scholars and practitioners focus on crucial stakeholders and variables related to outcomes (or benefits) of travel training. Second, the framework and the logic model help scholars and practitioners investigate not only whether the programs work, but also when, how, and why the programs work, thus providing the contingent and situational information of program effectiveness and efficiency. Such information can be useful to modify and improve the production and delivery of the programs. Finally, many travel training programs are often contracted out to the lower levels of government, nonprofits, or for-profit organizations. In this case, program owners (i.e. contractees) can obtain crucial information and knowledge from the framework and the logic model regarding which elements need to be considered for making contracts and ongoing oversight.

\section{Lessons Learned}

To build an integrative theory-driven framework and a logic model for evaluating travel training, the authors reviewed a wide range of academic journal articles, practical reports, and government documents regarding travel training, human resources training, and other related topics. As a result of the literature review, we found out a variety of important factors and the relationships between the factors related to travel training programs. If evaluators assess the effectiveness or efficiency of non-standardized human and social programs, just like travel training programs, characterized by high variability in program context, content, delivery system, and outcome, we recommend conducting a comprehensive in-depth literature review and 
building a theory-driven evaluation framework prior to their actual assessments. In addition, we recommend using exploratory qualitative research (e.g., expert panels, interviews, or the case study), because exploratory qualitative research may complement findings from the related literature and further develop a theory-driven evaluation framework.

Moreover, we recommend collecting information about quantitative or qualitative measurements and indicators available to evaluators and planners for their future research and program planning. For example, in the fields of human resources training, educational psychology, and cognitive and physical disabilities, there are already a variety of measurements and indicators (e.g., Australian Skills Quality Authority, 2013; Bauman et al., 2006; Colquitt et al., 2000). These measurement tools can be used for measuring respective elements of the integrative theory-driven framework and the logic model developed in this study. Hence, in the literature review process, it is important for evaluators and planners to search for and make a list of measurements and indicators for their future evaluation research and evidence-based program planning. 


\section{References}

AECOM. (2011). Travel training: Good practice guidance. London, U.K. Retrieved from https://www.gov.uk/government/uploads/system/uploads/attachment_data/file/4482/guidanc e.pdf

Agranoff, R. (2012). Collaborating to Manage: A Primer for the Public Sector. Washington D.C.: Georgetown University Press.

Agranoff, R., \& McGuire, M. (2003). Collaborative Public Management: New Strategies for Local Governments. Washington D.C.: Georgetown University Press.

Ansell, C., \& Gash, A. (2008). Collaborative governance in theory and practice. Journal of Public Administration Research and Theory, 18(4), 543-571.

Australian Skills Quality Authority. (2013). Learner questionnaire. Melbourne, Australia.

Babka, R. J., Cooper, J. F., \& Ragland, D. R. (2009). Evaluation of an urban travel training for older adults. Safe Transportation Research \& Education Center.

Baginski, J. G. (2008). Travel training: An exploration of the importance of public transportation for suburban students with disabilities. Marietta College.

Balog, J. N. (1997). Teaching passengers to use the fixed-route system - Travel training. Guidebook for attracting paratransit patrons to fixed-route services. Washington D.C.: National Academy Press.

Barbe, W. B., Swassing, R. H., \& Milone, M. N. (1979). Teaching through modality strengths: Concepts and practices. Zaner Bloser.

Bauman, A., Phongsavan, P., Schoeppe, S., \& Owen, N. (2006). Physical activity measurement: A primer for health promotion. Promotion and Education, 13(2), 92-103.

Bickman, L. (1989). Barriers to the use of program theory. Evaluation and Program Planning, 12(4), 387-390.

Bickman, L. (1996). The application of program theory to the evaluation of a managed mental health care system. Evaluation and Program Planning, 19(2), 111-119.

Bingham, R. D., \& Felbinger, C. L. (2002). Evaluation in practice: A methodological approach (2nd ed.). New York: Seven Bridges Press.

Brault, M. W. (2012). Americans with disabilities: 2010 household economic studies. Washington, D.C.

Bridger, K. (2011). Evaluative Review. Bradford, U.K.

Brousselle, A., \& Champagne, F. (2011). Program theory evaluation: Logic analysis. Evaluation and Program Planning, 34(1), 69-78.

Burkhardt, J. E., Bernstein, D. J., Kulbicki, K., Eby, D. W., Molnar, L. J., Nelson, C. A., \& McLary, J. M. (2014a). Travel training for older adults part I: A handbook. Washington, D.C. 
Burkhardt, J. E., Bernstein, D. J., Kulbicki, K., Eby, D. W., Molnar, L. J., Nelson, C. A., \& McLary, J. M. (2014b). Travel training for older adults part II: Research report and case studies. Washington, D.C.

Chen, H. T. (1990). Theory-driven evaluations. Thousand Oaks, CA: SAGE Publications, Inc.

Chen, H. T., \& Rossi, P. H. (1980). The multi-goal, theory-driven approach to evaluation: A model linking basic and applied social science. Social Forces, 59(1), 106-122.

Chen, H. T., \& Rossi, P. H. (1989). Issues in the theory-driven perspective. Evaluation and Program Planning, 12(4), 299-306.

Colquitt, J. a., LePine, J. a., \& Noe, R. a. (2000). Toward an integrative theory of training motivation: A meta-analytic path analysis of 20 years of research. Journal of Applied Psychology, 85(5), 678-707.

Cooksy, L. J., Gill, P., \& Kelly, P. A. (2001). The program logic model as an integrative framework for a multimethod evaluation. Evaluation and Program Planning, 24(2), 119128.

Coryn, C. L. S., Noakes, L. A., Westine, C. D., \& Schroter, D. C. (2011). A systematic review of theory-driven evaluation practice from 1990 to 2009. American Journal of Evaluation, 32(2), 199-226.

Davies, D. K., Stock, S. E., Holloway, S., \& Wehmeyer, M. L. (2010). Evaluating a GPS-based transportation device to support independent bus travel by people with intellectual disability. Intellectual and Developmental Disabilities, 48(6), 454-463.

Donaldson, S. I., \& Gooler, L. E. (2003). Theory-driven evaluation in action: Lessons from a \$20 million statewide work and health initiative. Evaluation and Program Planning, 26(4), 355366.

Easter Seals Project ACTION. (2004). Competencies for the practice of travel instruction and travel training. Washington, D.C. Retrieved from http://www.projectaction.org/ResourcesPublications/BrowseOurResourceLibrary/Resource SearchResults.aspx?org=a2GSpnDbruI=\&query=Competencies for the Practice of Travel Instruction

Easter Seals Project ACTION. (2012). A Cost-Benefit Model for Travel Training. Washington, D.C. Retrieved from http://www.projectaction.org/ResourcesPublications/BrowseOurResourceLibrary/Resource SearchResults.aspx?org=a2GSpnDbruI=\&query=Cost-Benefit Model for Travel Training\&utm_source=June+Extra\&utm_campaign=Veterans + Dialogue+Email+1\&utm_m edium=email

Easter Seals Project ACTION. (2013a). Considerations for Selecting and Hiring Travel Trainers A Compilation of Resources. Washington, D.C. Retrieved from http://www.projectaction.org/ResourcesPublications/BrowseOurResourceLibrary/Resource SearchResults.aspx?org=a2GSpnDbruI=\&query=Considerations for Selecting and Hiring Travel Trainers: A Compilation of Resources

Easter Seals Project ACTION. (2013b). Travel instruction - Familiarization , orientation and travel training. Retrieved December 4, 2014, from 
http://www.projectaction.org/Portals/3/MobilityManagement/Transportation Education/Module 4Travel Instruction -Travel Familiarization Orientation.pdf

Emerson, K., Nabatchi, T., \& Balogh, S. (2012). An integrative framework for collaborative governance. Journal of Public Administration Research and Theory, 22(1), 1-29.

Foley, D. J., Heimovitz, H. K., Guralnik, J. M., \& Brock, D. B. (2002). Driving life expectancy of persons aged 70 years and older in the United States. American Journal of Public Health, 92(8), 1284-1289.

Genworth. (2015). Annual median cost of long term care in the nation. Retrieved May 2, 2016, from https://www.genworth.com/corporate/about-genworth/industry-expertise/cost-ofcare.html

Groce, M. M. (1996a). A model of a travel training program-The New York City Board of Education travel training program. Transition Summary, 9.

Groce, M. M. (1996b). An introdcution to travel training. Transition Summary, 9.

Groce, M. M. (2000). Travel training: Getting out and about without fear. Exceptional Parent, 30(4).

Halcrow Group Limited. (2005). Travel training good-practice guidance. London, U.K. Retrieved from http://www.tfgm.com/accessible_transport/Documents/training_guide.pdf

Helitzer, D., Hollis, C., Hernandez, B. U. De, Sanders, M., Roybal, S., \& Van Deusen, I. (2010). Evaluation for community-based programs: The integration of logic models and factor analysis. Evaluation and Program Planning, 33(3), 223-233.

James, W. B., \& Gardner, D. L. (1995). Learning styles: Implications for distance learning. New Directions for Adult and Continuing Education, 67, 19-31.

Joffee, E. (1996). Teaching travel skills to persons who are blind or visually impaired. Transition Summary, 9.

Kaplan, S. A., \& Garrett, K. E. (2005). The use of logic models by community-based initiatives. Evaluation and Program Planning, 28(2), 167-172.

Kirkland, D. L. (1998). The four levels of evaluation. In S. M. Brown \& C. J. Seidner (Eds.), Evaluating corporate training: Models and issues. Norwell, MA: Kluwer Academic Publishers.

Knowlton, L. . W., \& Phillips, C. C. (2009). The logic model guidebook: Better strategies for great results. Thousand Oaks, CA: Sage Publications, Inc.

LaGrow, S., Wiener, W., \& LaDuke, R. (1990). Independent travel for developmentally disabled persons: A comprehensive model of instruction. Research in Developmental Disabilities, 11(3), 289-301.

Laurent Clerc National Deaf Education Center. (2007). Students on the go, safely and independently-A travel training manual. Washington, D.C. Retrieved from http://www.gallaudet.edu/documents/clerc/cc-full-manual.pdf

Lipsey, M. W., \& Pollard, J. A. (1989). Driving toward theory in program evaluation: More models to choose from. Evaluation and Program Planning, 12(4), 317-328. 
Mark, M. M., Henry, G. T., \& Julnes, G. (2000). Evaluation: An integrated framework for understanding, guiding, and improving policies and programs. San Francisco, CA: JosseyBass.

Maryland Transit Association. (2007). Comparison of capital costs for fixed-route bus stop improvements to paratransit operating cost. Retrieved September 20, 2014, from http://www.ilru.net/html/training/webcasts/handouts/2007/12-12MG/Busstopimpovements.doc

Mccarthy, D. P., Shannon, L., \& Wolf-Branigin, K. (2010). Current practices used by travel trainers for seniors. Washington, D.C. Retrieved from http://www.safeandmobileseniors.org/pdfs/Current Practices Used by Travel Trainers for Seniors.pdf

McLaughlin, J. a., \& Jordan, G. B. (1999). Logic models: a tool for telling your programs performance story. Evaluation and Program Planning, 22(2), 65-72.

Millar, A., Simeone, R. S., \& Carnevale, J. T. (2001). Logic models: A systems tool for performance management. Evaluation and Program Planning, 24(1), 73-81.

Musselwhite, C. (2010). The role of education and training in helping older people to travel when giving-up driving. International Journal of Education and Ageing, 1(2), 197-212.

Neef, N. A., Iwata, B. A., \& Page, T. J. (1978). Public transportation training: In vivo versus classroom instruction. Journal of Applied Behavior Analysis, 3(3), 331-344.

Neff, J., \& Dickens, M. (2013). 2013 Public Transportation Fact Book. Washington, D.C. Retrieved from http://www.apta.com/resources/statistics/Documents/FactBook/2013APTA-Fact-Book.pdf

Nesman, T. M., Batsche, C., \& Hernandez, M. (2007). Theory-based evaluation of a comprehensive Latino education initiative: an interactive evaluation approach. Evaluation and Program Planning, 30(3), 267-81.

Ride Connection. (2009). A Guide to Travel Training. Portland, OR. Retrieved from https://www.rideconnection.org/ride/LinkClick.aspx?fileticket=dwrbjbCP7_o\%3D\&tabid=6 9

Rossi, P. H., Freeman, H. E., \& Lipsey, M. W. (1999). Evaluation: A systematic approach (6th ed.). Thousand Oaks, CA: SAGE Publications, Inc.

Ruegg, R., \& Feller, I. (2003). A toolkit for evaluating public R\&D investment. Gaithersburg, MD.

Samberg, S. K. (1996). Travel training for people with physical disabilities. Transition Summary, 9.

Shopland, N., Lewis, J., Brown, D. J., \& Dattani-Pitt, K. (2004). Design and evaluation of a flexible travel training environment for use in a supported employment setting. In Fifth International Conference on Disability, Virtual Reality and Assciated Technologies (pp. 6976). Oxford, UK.

SQW. (2009). An independent travel training model. 
Stanley, J., Hensher, D. A., Stanley, J., Currie, G., Greene, W. H., \& Vella-brodrick, D. (2011). Social exclusion and the Value of mobility. Journal of Transport Economics and Policy, 45(2), 197-222.

Stevens, N., Battellino, H., \& Pedler, K. (2013). Evaluating travel training in Northern Sydney: Methodological and practical issues. In Australasian Transport Research Forum 2013. Brisbane, Australia.

Voorhees, P. J. (1996). Travel training for persons with cognitive or physical disabilities: An overview. Transition Summary, 9.

Walshe, K. (2007). Understanding what works-and why-in quality improvement: The need for theory-driven evaluation. International Journal for Quality in Health Care, 19(2), 57-59.

Welsh Local Government Association, Welsh Assembly Government, \& the City of Cardiff Council. (2011). Independent travel training scheme pilot project final report. Retrieved from http://www.wlga.gov.uk/school-transport-project-reports/independent-travel-trainingscheme-pilot-project-final-report-march-2011/

Werner, C. A. (2011). The older population: 2010. 2010 Census Briefs. Washington, D.C.

Wolf-Branigin, K., \& Wolf-Branigin, M. (2010). A Travel training cost-benefit model for people with disabilities, public transportation agencies, and communities. In The 12th International Conference on Mobility and Transport for Elderly and Disabled Persons. Hong Kong.

Wolf-Branigin, K., Wolf-Branigin, M., Culver, J. D., \& Welch, K. (2012). Can travel training services save public transportation money? TR News, 36-38.

Wolf-Branigin, M., \& Wolf-Branigin, K. (2008). The emerging field of travel training services: A systems perspective. Journal of Public Transportation, 11(3), 109-123. 
Table 1. Categorization of Prior Evaluation Studies on Travel Training Programs

\begin{tabular}{|c|c|c|c|}
\hline & \multicolumn{2}{|c|}{ Types of evaluation } \\
\hline & & Impact studies & Cost-benefit analysis \\
\hline \multirow{2}{*}{$\begin{array}{l}\text { Purposes } \\
\text { of } \\
\text { research }\end{array}$} & $\begin{array}{l}\text { Development of } \\
\text { evaluation models } \\
\text { (or tools) }\end{array}$ & $\begin{array}{l}\text { - AECOM (2011) } \\
\text { - Laurent Clerc National Deaf } \\
\text { Education Center (2007) }\end{array}$ & $\begin{array}{l}\text { - AECOM (2011) } \\
\text { - Easter Seals Project ACTION } \\
\text { (2012) } \\
\text { - Stevens et al. (2013) } \\
\text { - SQW (2009) } \\
\text { - Wolf-branigin \& Wolf- } \\
\text { branigin (2010) }\end{array}$ \\
\hline & $\begin{array}{l}\text { Application of } \\
\text { evaluation models } \\
\text { (or tools) }\end{array}$ & $\begin{array}{l}\text { - Babka et al. (2009) } \\
\text { - Baginski (2008) } \\
\text { - Bridger (2011) } \\
\text { - Neef et al. (1978) } \\
\text { - Welsh Local Government } \\
\text { Association et al. (2011) }\end{array}$ & $\begin{array}{l}\text { - Bridger (2011) } \\
\text { - Neef et al. (1978) } \\
\text { - Stevens et al. (2013) } \\
\text { - Welsh Local Government } \\
\text { Association et al. (2011) } \\
\text { - Wolf-branigin et al. (2012) }\end{array}$ \\
\hline
\end{tabular}




\section{Table 2. Prior Evaluation Studies on Travel Training}

\begin{tabular}{|c|c|c|c|}
\hline Authors & Key Contents & Strengths & Weaknesses \\
\hline $\begin{array}{l}\text { AECOM } \\
(2011)\end{array}$ & $\begin{array}{l}\text { - Provided a practical evaluation } \\
\text { framework for monitoring and } \\
\text { cost-benefit analysis. }\end{array}$ & $\begin{array}{l}\text { - Suggested potential indicators for } \\
\text { monitoring and cost-benefit } \\
\text { analysis. } \\
\text { - Considered diverse stakeholders. }\end{array}$ & $\begin{array}{l}\text { - Focused primarily on immediate } \\
\text { outputs. } \\
\text { - Not considered discount rates. }\end{array}$ \\
\hline $\begin{array}{l}\text { Babka, } \\
\text { Cooper, \& } \\
\text { Ragland } \\
(2009)\end{array}$ & $\begin{array}{l}\text { - Measured the impacts of travel } \\
\text { training on trainees' knowledge } \\
\text { of local public transit. }\end{array}$ & $\begin{array}{l}\text { - Provided a detailed description of } \\
\text { participants' travel habits, } \\
\text { attitudes, and concerns towards } \\
\text { public transit. }\end{array}$ & $\begin{array}{l}\text { - Relatively small sample size (50 } \\
\text { older people) } \\
\text { - No control or comparison group }\end{array}$ \\
\hline $\begin{array}{l}\text { Baginski } \\
\text { (2008) }\end{array}$ & $\begin{array}{l}\text { - Measured the impacts of travel } \\
\text { training on trainees' perceptions } \\
\text { of independence, self- } \\
\text { confidence, and self-advocacy. }\end{array}$ & $\begin{array}{l}\text { - Employed mixed research } \\
\text { methods (i.e. quantitative and } \\
\text { qualitative). }\end{array}$ & $\begin{array}{l}\text { - Too small sample size (15 } \\
\text { students with disabilities) } \\
\text { - No control or comparison group }\end{array}$ \\
\hline $\begin{array}{l}\text { Bridger } \\
\text { (2011) }\end{array}$ & $\begin{array}{l}\text { - Illustrated direct and indirect } \\
\text { impacts of travel training. } \\
\text { - Calculated cost-savings } \\
\text { generated by travel training }\end{array}$ & $\begin{array}{l}\text { - Considered diverse stakeholders. } \\
\text { - Compare the cost of travel } \\
\text { training and the cost of paratransit } \\
\text { services. }\end{array}$ & $\begin{array}{l}\text { - Focused on outputs } \\
\text { - Not considered discount rates with } \\
\text { regard to costs and benefits of travel } \\
\text { training }\end{array}$ \\
\hline $\begin{array}{l}\text { Easter Seals } \\
\text { Project } \\
\text { ACTION } \\
(2012)\end{array}$ & $\begin{array}{l}\text { - Developed a monthly budget } \\
\text { worksheet for training } \\
\text { organizations. }\end{array}$ & $\begin{array}{l}\text { - Provided detailed cost categories } \\
\text { of travel training. }\end{array}$ & $\begin{array}{l}\text { - Focused on training providers } \\
\text { rather than other relevant } \\
\text { organizations and stakeholders. } \\
\text { - Not considered discount rates. }\end{array}$ \\
\hline $\begin{array}{l}\text { LCNDEC } \\
(2007)\end{array}$ & $\begin{array}{l}\text { - Provided practical post- } \\
\text { assessment forms }\end{array}$ & $\begin{array}{l}\text { - Provided various examples of } \\
\text { post-assessment questions }\end{array}$ & $\begin{array}{l}\text { - Focused primarily on participants' } \\
\text { knowledge of local public transit } \\
\text { and feeling about independent } \\
\text { traveling. }\end{array}$ \\
\hline $\begin{array}{l}\text { Neef, Iwata, } \\
\text { \& Page } \\
\text { (1978) }\end{array}$ & $\begin{array}{l}\text { - Measured the relative } \\
\text { effectiveness and efficiency of } \\
\text { two different training } \\
\text { approaches. }\end{array}$ & $\begin{array}{l}\text { - Compared the effectiveness and } \\
\text { efficiency of several approaches to } \\
\text { travel training delivery. }\end{array}$ & $\begin{array}{l}\text { - Too small sample size. } \\
\text { - Considered variables that could be } \\
\text { easily translated into monetary } \\
\text { terms. }\end{array}$ \\
\hline $\begin{array}{l}\text { Stevens, } \\
\text { Battellino, } \\
\text { \& Pedler } \\
(2013)\end{array}$ & $\begin{array}{l}\text { - Developed a broad cost-benefit } \\
\text { analysis framework for travel } \\
\text { training and applies the } \\
\text { framework to an actual case in } \\
\text { Northern Sydney. }\end{array}$ & $\begin{array}{l}\text { - Took into account multi- } \\
\text { dimensions related to the benefits } \\
\text { of travel training. } \\
\text { - Employed discount rates. }\end{array}$ & $\begin{array}{l}\text { - Focused on variables that could be } \\
\text { relatively easily translated into } \\
\text { monetary terms. } \\
\text { - Not considered overhead } \\
\text { administrative costs. }\end{array}$ \\
\hline $\begin{array}{l}\text { SQW } \\
\text { (2009) }\end{array}$ & $\begin{array}{l}\text { - Developed a cost-benefit } \\
\text { analysis framework to calculate } \\
\text { the financial savings. }\end{array}$ & $\begin{array}{l}\text { - Provided user-friendly excel- } \\
\text { based templates for cost-benefit } \\
\text { analysis of travel training. }\end{array}$ & $\begin{array}{l}\text { - Defined costs and benefits } \\
\text { narrowly. } \\
\text { - Not considered discount rates. }\end{array}$ \\
\hline $\begin{array}{l}\text { Welsh Local } \\
\text { Government } \\
\text { Association } \\
\text { et al. (2011) }\end{array}$ & $\begin{array}{l}\text { - Conducted (1) descriptive } \\
\text { evaluation on the outcomes and } \\
\text { benefits; and (2) cost-benefit } \\
\text { analysis. }\end{array}$ & $\begin{array}{l}\text { - Considered relatively various } \\
\text { outcomes and financial benefits of } \\
\text { travel training from the } \\
\text { intermediate and long-term } \\
\text { perspectives. }\end{array}$ & - Not considered discount rates. \\
\hline $\begin{array}{l}\text { Wolf- } \\
\text { Branigin \& } \\
\text { Wolf- } \\
\text { Branigin } \\
(2010) \\
\end{array}$ & $\begin{array}{l}\text { - Developed a cost-benefit } \\
\text { analysis framework for travel } \\
\text { training. }\end{array}$ & $\begin{array}{l}\text { - Provided three different kinds of } \\
\text { cost-benefit model templates for } \\
\text { trainees, public transportation } \\
\text { agencies, and the community at } \\
\text { large. }\end{array}$ & $\begin{array}{l}\text { - Focused only on variables that } \\
\text { could be easily translated into } \\
\text { monetary terms. } \\
\text { - Not considered discount rates. }\end{array}$ \\
\hline $\begin{array}{l}\text { Wolf- } \\
\text { Branigin, } \\
\text { Wolf- } \\
\text { Branigin, } \\
\text { Culver, \& } \\
\text { Welch } \\
\text { (2012) }\end{array}$ & $\begin{array}{l}\text { - Applied the cost-benefit model } \\
\text { created by Wolf-Branigin and } \\
\text { Wolf-Branigin }(2010,2012) \text { to } \\
\text { three transportation agencies } \\
\text { providing travel training. }\end{array}$ & $\begin{array}{l}\text { - Provided results of comparative } \\
\text { cost-benefit analysis with regard to } \\
\text { three transportation agencies. }\end{array}$ & $\begin{array}{l}\text { - Not considered the resources and } \\
\text { costs of other relevant } \\
\text { organizations. } \\
\text { - Not considered discount rates. }\end{array}$ \\
\hline
\end{tabular}


Table 3. A Logic Model of Travel Training Programs

\begin{tabular}{|c|c|c|}
\hline Resources & Activities & Outputs \\
\hline $\begin{array}{l}\text { Trainees } \\
\text {-Motivation for training } \\
\text {-Cognitive and physical skills } \\
\text {-Prior experience with public transportation }\end{array}$ & $\begin{array}{l}\text { Trainees } \\
\text {-Get information of and applying for training } \\
\text {-Attend pre-assessment, classroom and onsite training, and } \\
\text { post-evaluation }\end{array}$ & \multirow{8}{*}{$\begin{array}{l}\text {-Quality of a recruitment plan made by the } \\
\text { training providers } \\
\text {-Number and quality of brochures and } \\
\text { flyers for recruitment } \\
\text {-Number and quality of curriculum and } \\
\text { learning resources } \\
\text {-Number of application packets reviewed by } \\
\text { the training providers } \\
\text {-Number of enrolled trainees } \\
\text {-Number and quality of pre-assessments } \\
\text {-Number and quality of individualized goals } \\
\text { and training plans developed } \\
\text {-Number and quality of classroom and } \\
\text { onsite training sessions } \\
\text {-Number and quality of post-evaluations } \\
\text {-Numbers and quality of follow-up services } \\
\text {-Number of trainees who complete training }\end{array}$} \\
\hline $\begin{array}{l}\text { Parents, Guardians, and Caregivers } \\
\text {-Time spent for helping trainees attend training } \\
\text {-Personal vehicles to take trainees to trainers } \\
\text {-Emotional supports for trainees }\end{array}$ & $\begin{array}{l}\text { Parents, Guardians, and Caregivers } \\
\text {-Get information of and applying for training } \\
\text {-Give trainees rides to attend training } \\
\text {-Provide emotional supports }\end{array}$ & \\
\hline $\begin{array}{l}\text { Schools and School Districts (regarding } \\
\text { students with disabilities) } \\
\text { - Teachers } \\
\text { - Administrative staff for individualized } \\
\text { education programs (IEP) } \\
\text { - Budgets for training }\end{array}$ & $\begin{array}{l}\text { Schools and School Districts (regarding students with } \\
\text { disabilities) } \\
\text {-Provide parents and guardians with information and } \\
\text { consulting services of training } \\
\text {-Administrative services regarding the training applications } \\
\text { and changes in students' IEP as a result of travel trainings } \\
\text {-Creating and managing budgets for training }\end{array}$ & \\
\hline $\begin{array}{l}\text { Training Providers } \\
\text {-Trainers and administrative staff } \\
\text {-Grants for operating training } \\
\text {-Occupancy/utilities, education materials, and } \\
\text { office supplies }\end{array}$ & $\begin{array}{l}\text { Training Providers } \\
\text {-Recruiting trainees } \\
\text {-Developing curriculum, learning resources, and instructional } \\
\text { materials } \\
\text {-Conducting pre-assessment and environmental analysis } \\
\text {-Developing individualized goals and training plans } \\
\text {-Classroom and one-on-one training } \\
\text {-Post-evaluation and final written evaluation report } \\
\text {-Hiring trainers, supervisors, and administrative staff } \\
\text {-Continuing education (e.g., attending conferences and } \\
\text { workshops) } \\
\text {-Applying for and accepting grants, managing personnel } \\
\text { expenses, accounting, and paying for occupancy/utilities/ } \\
\text { purchasing and managing equipment, materials, and supplies }\end{array}$ & \\
\hline $\begin{array}{l}\text { Public Transportation Authorities } \\
\text { - Fixed-route transportation systems } \\
\text { - Reduced fare and/or free rider permits for } \\
\text { trainees and instructors } \\
\text { - Budgets for training }\end{array}$ & $\begin{array}{l}\text { Public Transportation Authorities } \\
\text {-Providing equipment for trainees (e.g., wheelchair lifts and } \\
\text { kneeling capability) } \\
\text {-Training bus drivers to assist trainees to board and stay safe } \\
\text { on the bus } \\
\text {-Issuing reduced fare and/ or free rider permits for trainees } \\
\text { and trainers } \\
\text {-Creating and managing budgets for the training programs }\end{array}$ & \\
\hline $\begin{array}{l}\text { Other Public Agencies at the Three Levels of } \\
\text { Government } \\
\text { - Human, financial, and in-kind resources from } \\
\text { other public agencies to support training }\end{array}$ & $\begin{array}{l}\text { Other Public Agencies at the Three Levels of Government } \\
\text {-Assigning public employees to assist training } \\
\text {-Allocating local, state, and/or federal funds to operating } \\
\text { training } \\
\text { - Donating in-kind resources }\end{array}$ & \\
\hline $\begin{array}{l}\text { Collaboration and Partnership } \\
\text {-Referral and communication systems } \\
\text {-Prior history of collaboration/partnership - } \\
\text {-Shared understanding } \\
\text {-Commitment to the training programs } \\
\text {-Mutual trust }\end{array}$ & $\begin{array}{l}\text { Collaboration and Partnership } \\
\text {-Referring people to the training providers } \\
\text {-Making a contracting-out agreement with contractors } \\
\text {-Allocating financial resources to contractors } \\
\text {-Monitoring and evaluating the training programs } \\
\text {-Mobilizing shared resources }\end{array}$ & \\
\hline $\begin{array}{l}\text { Community at Large } \\
\text {-Community culture promoting diversity } \\
\text {-Political supports for the travel training } \\
\text { programs } \\
\text {-Volunteers who willingly commit their spare } \\
\text { time and resources to the travel training } \\
\text { programs (e.g., volunteer trainers) }\end{array}$ & $\begin{array}{l}\text { Community at Large } \\
\text {-Carrying out a non-political and political campaign for the } \\
\text { training programs } \\
\text {-Establishing a group of volunteers and supporters for the } \\
\text { training programs }\end{array}$ & \\
\hline
\end{tabular}


Table 3. A Logic Model of Travel Training Programs (continued)

\begin{tabular}{|c|c|c|}
\hline Short-term Outcomes & Intermediate Outcomes & Long-term outcomes \\
\hline $\begin{array}{l}\text { Trainees } \\
\text { Benefits for both people with disabilities and } \\
\text { older people } \\
\text {-Satisfaction with application/referral, pre- } \\
\text { assessments, individualized training planning, } \\
\text { classroom and onsite training, and post- } \\
\text { evaluation } \\
\text {-Changes in attitudes towards traveling } \\
\text { independently } \\
\text {-Increased knowledge and skills } \\
\text {-Increased uses of fixed-route public } \\
\text { transportation } \\
\text {-Increased moderate-intensity physical activity }\end{array}$ & $\begin{array}{l}\text { Trainees } \\
\text { Benefits for both people with disabilities and older } \\
\text { people } \\
\text {-Increased access to healthcare and public social } \\
\text { services, markets for goods and services, and social and } \\
\text { leisure activities } \\
\text {-Increased independence, confidence, and self-esteem } \\
\text {-Saved money from increased access to a wider range of } \\
\text { stores } \\
\text {-Cost avoidance due to increased access to services } \\
\text { Benefits for students with disabilities } \\
\text {-Increased access to post-secondary education and } \\
\text { training and employment } \\
\text {-Decreased likelihood of developing behavior problems } \\
\text { Benefits for older people } \\
\text {-Aging in place } \\
\text {-Reduced or deferred costs of nursing homes }\end{array}$ & $\begin{array}{l}\text { Trainees (both people with disabilities and older } \\
\text { people) } \\
\text {-Improved economic opportunities and benefits } \\
\text {-Improved physical, mental, and social well-being }\end{array}$ \\
\hline $\begin{array}{l}\text { Parents, Guardians, and Caregivers } \\
\text {-Reduction in care responsibilities }\end{array}$ & $\begin{array}{l}\text { Parents, Guardians, and Caregivers } \\
\text {-More time and opportunities for education and training, } \\
\text { employment, and social, recreational, and leisure } \\
\text { activities }\end{array}$ & $\begin{array}{l}\text { Parents, Guardians, and Caregivers } \\
\text {-Improved economic opportunities and benefits } \\
\text {-Improved mental and social well-being }\end{array}$ \\
\hline $\begin{array}{l}\text { Schools and School Districts (regarding } \\
\text { students with disabilities) } \\
\text {-More engaged and motivated students with } \\
\text { disabilities } \\
\text {-Decreased students with disabilities using } \\
\text { school buses } \\
\text {-Decreased students in the list of the } \\
\text { transportation section of the individual } \\
\text { education program }\end{array}$ & $\begin{array}{l}\text { Schools and School Districts (regarding students with } \\
\text { disabilities) } \\
\text {-Positive classroom/school climate } \\
\text {-Reduced cost of operating school bus for student with } \\
\text { disabilities } \\
\text {-Reduction in administrative and human resource costs }\end{array}$ & $\begin{array}{l}\text { Schools/Colleges (regarding students with } \\
\text { disabilities) } \\
\text {-Positive classroom/school climate } \\
\text {-Cost savings from the reduced use of school bus } \\
\text {-Cost savings from the reduction in administrative } \\
\text { and human resource costs }\end{array}$ \\
\hline $\begin{array}{l}\text { Training Providers } \\
\text {-Increase in the number of students applying to } \\
\text { the programs }\end{array}$ & $\begin{array}{l}\text { Training Providers } \\
\text {-Increased funding for the programs }\end{array}$ & $\begin{array}{l}\text { Training Program Providers } \\
\text {-Financial sustainability of the programs } \\
\text {-Improved public recognition and reputation }\end{array}$ \\
\hline \multirow[t]{2}{*}{$\begin{array}{l}\text { Public Transportation Authorities } \\
\text {-Reduced costs of operating paratransit } \\
\text { services }\end{array}$} & $\begin{array}{l}\text { Public Transportation Authorities } \\
\text {-Increase in revenue from the increased use of fixed- } \\
\text { route public transit } \\
\text {-Reduced costs of operating paratransit services }\end{array}$ & $\begin{array}{l}\text { Public Transportation authorities } \\
\text {-Financial sustainability } \\
\text {-Increased public supports }\end{array}$ \\
\hline & $\begin{array}{l}\text { Other Public Agencies at the Three Levels of } \\
\text { Government } \\
\text {-Reduced reliance on welfare benefits owing to } \\
\text { improved economic opportunities } \\
\text {-Reduced demand on social and medical services due to } \\
\text { improved physical and mental health }\end{array}$ & $\begin{array}{l}\text { Other Public Agencies } \\
\text {-Cost avoidance from reduced reliance on welfare } \\
\text { benefits } \\
\text {-Cost avoidance from reduced demand on social } \\
\text { and medical services } \\
\text {-Increased revenue from paying more taxes due to } \\
\text { improved economic opportunities (e.g., property } \\
\text { taxes, sales taxes, and income taxes) }\end{array}$ \\
\hline \multirow[t]{2}{*}{$\begin{array}{l}\text { Collaboration and Partnership } \\
\text {-Enhanced communication, shared } \\
\text { understanding, and mutual trust }\end{array}$} & $\begin{array}{l}\text { Collaboration and Partnership } \\
\text {-Increase in shared resources }\end{array}$ & $\begin{array}{l}\text { Collaboration and Partnership } \\
\text {-Improved collaborative capacity for providing the } \\
\text { training programs }\end{array}$ \\
\hline & $\begin{array}{l}\text { Community at Large } \\
\text {-Increase in a well-educated workforce } \\
\text {-Spending more in local markets and stores } \\
\text {-Environmental benefits due to increased use of } \\
\text { sustainable transportation (e.g., reduction in CO2 } \\
\text { emissions) } \\
\text {-Increased diversity of people involving the community }\end{array}$ & $\begin{array}{l}\text { Community at Large } \\
\text {-Long-term economic benefits from a well- } \\
\text { educated workforce and increase in trainees' } \\
\text { spending } \\
\text {-Long-term environmental benefits from increased } \\
\text { use of sustainable transportation } \\
\text {-Building a community of diversity }\end{array}$ \\
\hline
\end{tabular}


Figure 1. Building an integrative theory-driven framework for evaluating travel training

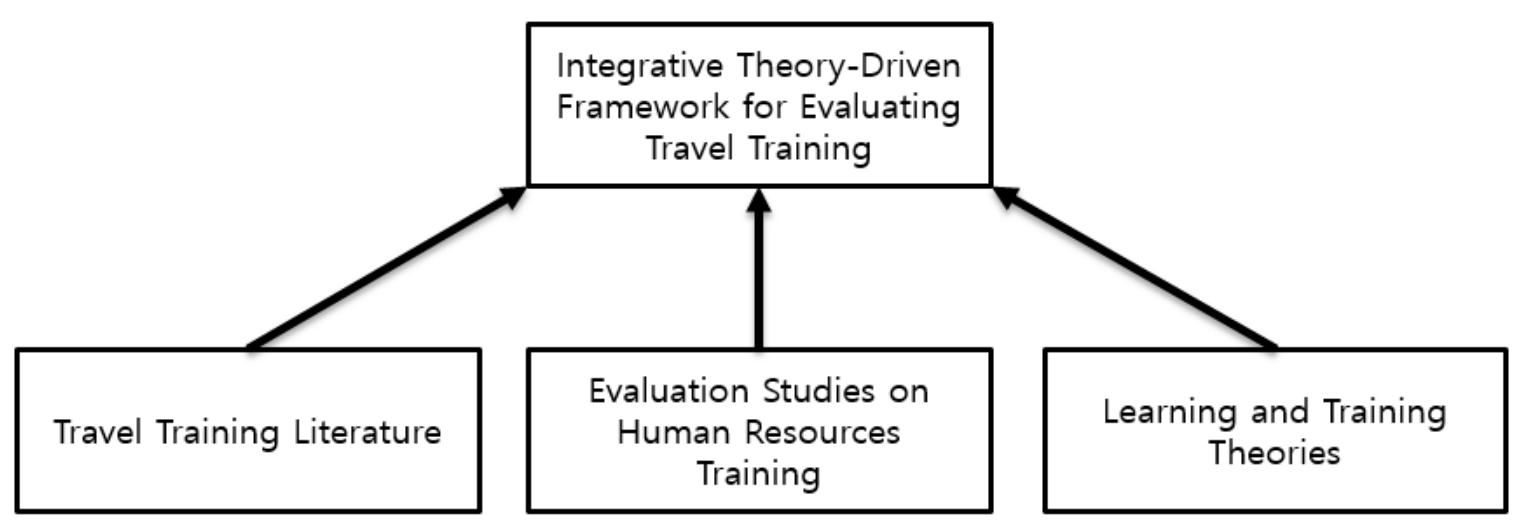


Figure 2. Integrative theory-driven framework for evaluating travel training program

\section{Outcomes \& Benefits}

\section{Travel Training Program}

\section{Organization-level Factors}

- Types of travel training providers

- Approaches to travel training

- Financial sustainability

Instructors' Skills and Competencies

-Knowledge about disabilities, the transportation

system, and travel skills and techniques

Environmental and risk analysis

- Planning personalized instruction

- Pre- and post-evaluation

Administration and supervision of travel training

Training-related Factors

- Training models

- Training contents and topics

Training aids and tools

\section{Moderators \& Mediators}

Travel Infrastructure and Environment

- Training in rural and suburban areas

- Length and easy of the journey

Individual Trainees' Characteristics

- Age

Type and severity of disability

- Anxiety and fear towards training

- Motivation and commitment to training

- Learning style

- Prior experience of using public transportation

Behavior and Involvement of Parents,

Guardians, and Caregivers

- Overprotection, resistance, and anxiety

Communication with training instructors

- Trust in training instructors

Collaboration and Partnership among

\section{Stakeholders}

-The context and environment (i.e. resource

conditions, program legal frameworks, pre-history

of collaboration, and network connectedness)

- The collaborative process (i.e. communication and

deliberation, mutual trust, shared understanding,

and leadership)
Individual Trainees

Benefits for both people with disabilities and older

people

- Trainees' satisfaction with travel training

Changes in attitudes towards independent travel

Increased use of fixed-route public transportation

Increased access to healthcare and social services,

markets for goods and services, and social activities

- Increased self-confidence and self-esteem

Saved money

Benefits for students with disabilities

- Increased access to education and employment

Decreased likelihood of developing behavior problems

Benefits for older people

- Aging in place and reduced costs of nursing homes

Parents, Guardians, and Caregivers

Reduced care responsibilitie

Increased time and opportunities for education,

employment, and social activities

Improved economic, mental, and social wellbeing

Schools and School Districts

Financial, administrative, and human resource cost

saving and avoidance

Positive classroom/school climate

Travel Training Providers

Financial sustainability

- Positive recognition and reputation

Public Transportation Authorities and Operators

- Financial saving and avoidance

- Increase in public transportation patronage

- Positive political supports

Other Public Agencies at the Three Levels of

Governments

Reduced reliance on social welfare benefits

Reduced government spending for medical services

- Increased public revenues

Community at Large

Improved social inclusion

Economic benefits

Environmental benefits 


\section{APPENDIX}

Figures 1 -10

\section{Impact of Student Assessment}

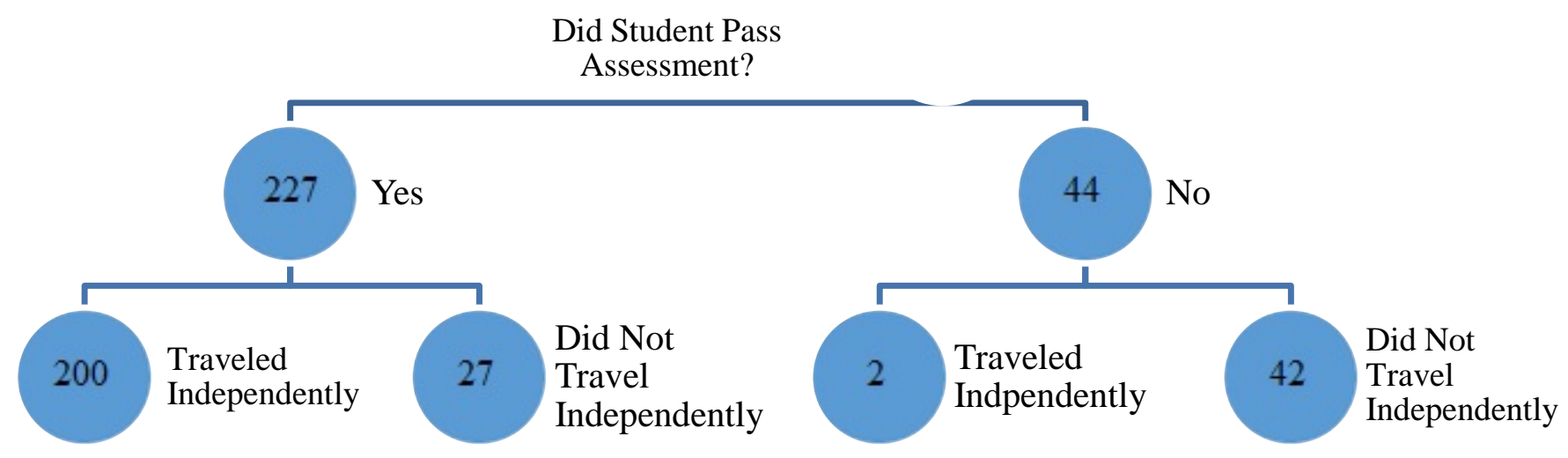

Figure 2 Impact of Assessment

Reasons for NOT traveling independently

\begin{tabular}{|l|l|l|}
\hline & Student did not pass assessment & Student passed assessment \\
\hline Safety Concerns & $46 \%$ & $40 \%$ \\
\hline $\begin{array}{l}\text { Parent/guardian decided not to } \\
\text { travel independently }\end{array}$ & $23 \%$ & $26 \%$ \\
\hline $\begin{array}{l}\text { Student decided not to travel } \\
\text { independently }\end{array}$ & $9 \%$ & $11 \%$ \\
\hline Health Concerns & $6 \%$ & $6 \%$ \\
\hline Other & $16 \%$ & $17 \%$ \\
\hline
\end{tabular}

Figure 2 Reasons for not Traveling Independently

Note: 6 students listed two reasons and 1 student listed three reasons

\section{Number of Training Days and Did Student Complete Training and Begin Traveling Independently?}

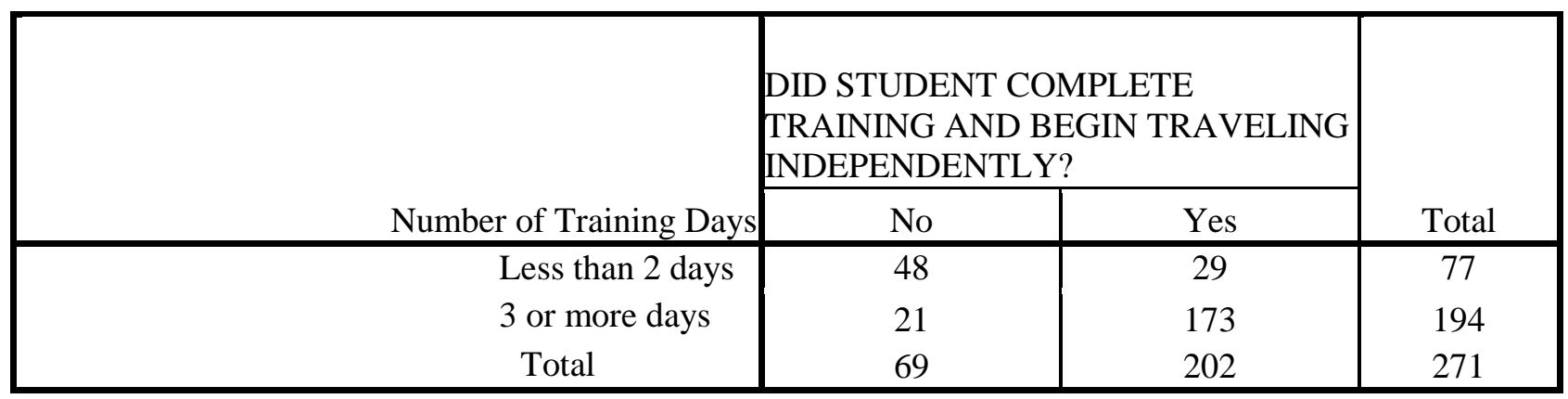

Figure 3

Note: See appendix for the number of students who passed assessment and their number of training days. 


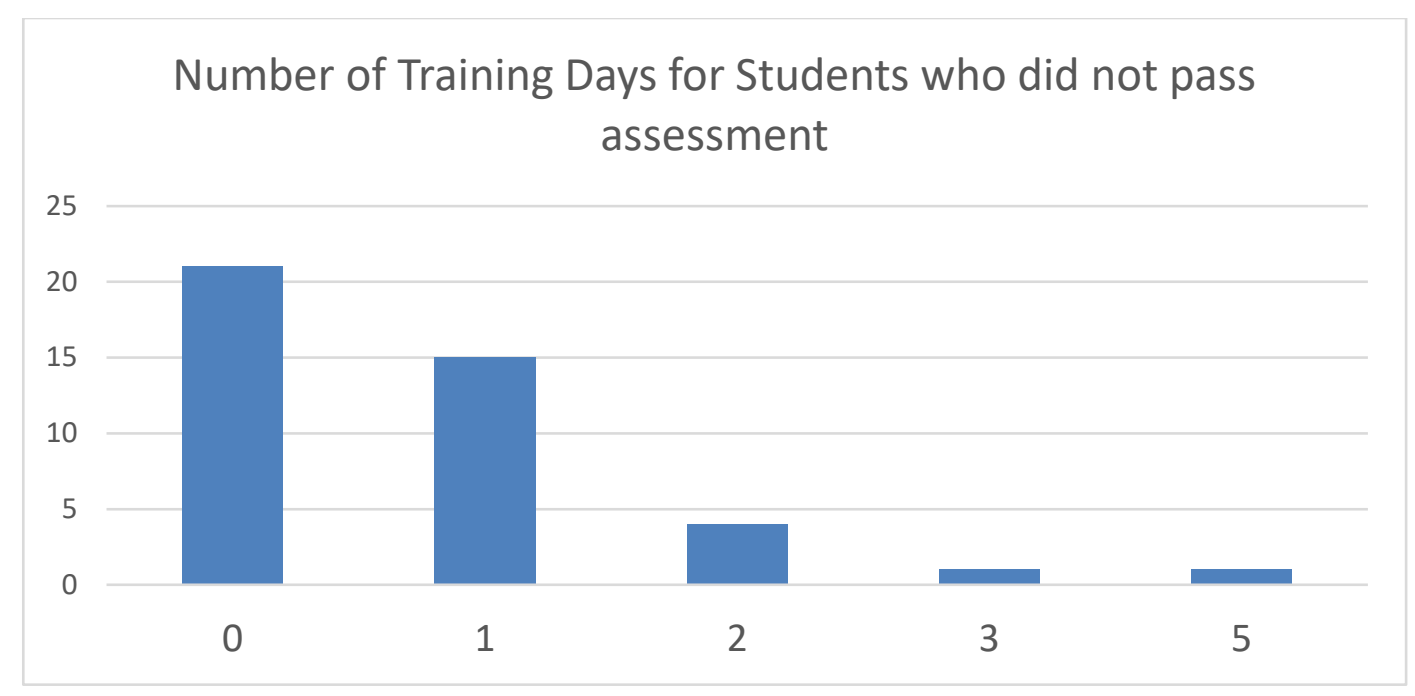

Figure 4

Modes To and From school and Did Student complete training and begin traveling independently

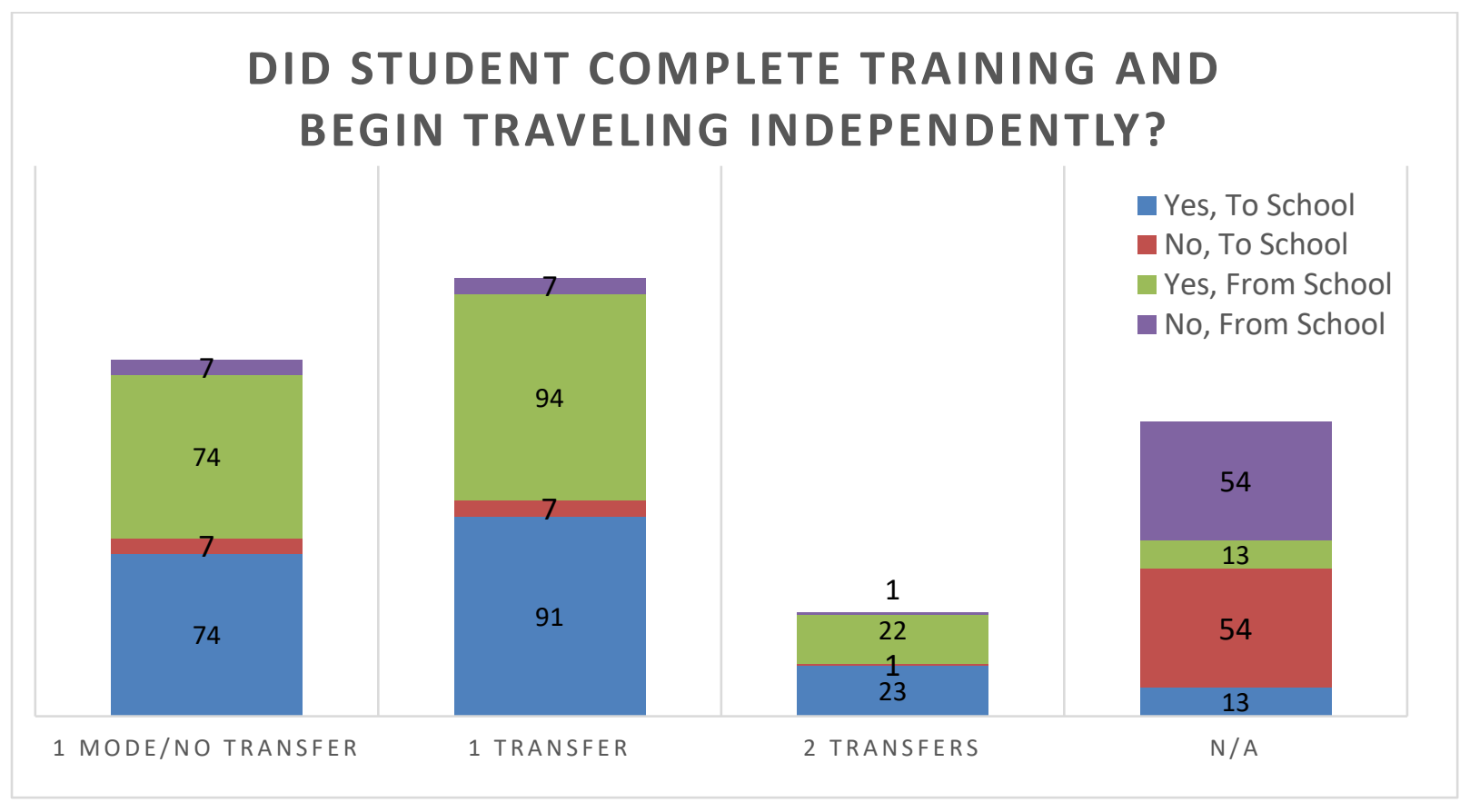

Figure 5 
Primary Disability and DID STUDENT COMPLETE TRAINING AND BEGIN

TRAVELING INDEPENDENTLY?

\begin{tabular}{|c|c|c|c|c|c|}
\hline & & & $\begin{array}{r}\text { DID STUDEN } \\
\text { TRAINING } \\
\text { TRAVELING INL }\end{array}$ & $\begin{array}{l}\text { APLETE } \\
\text { EGIN } \\
\text { IDENTLY? }\end{array}$ & \\
\hline & & & No & Yes & Total \\
\hline Primary Disability & HI Disability & Count & 21 & 97 & 118 \\
\hline & & $\%$ of Total & $7.7 \%$ & $35.8 \%$ & $43.5 \%$ \\
\hline & LI Disability & Count & 48 & 105 & 153 \\
\hline & & $\%$ of Total & $17.7 \%$ & $38.7 \%$ & $56.5 \%$ \\
\hline Total & & Count & 69 & 202 & 271 \\
\hline & & $\%$ of Total & $25.5 \%$ & $74.5 \%$ & $100.0 \%$ \\
\hline
\end{tabular}

Figure 6

\section{Data Collection Recommendations}

\begin{tabular}{|l|l|}
\hline \multicolumn{1}{|c|}{ Variable } & \multicolumn{1}{|c|}{ Function } \\
\hline $\begin{array}{l}\text { Length of trainees' journey to and from } \\
\text { school }\end{array}$ & $\begin{array}{l}\text { Can be indicative to the ease of journey and } \\
\text { also may explain the travel infrastructure }\end{array}$ \\
\hline $\begin{array}{l}\text { Trainee's knowledge, usage, and } \\
\text { experience/history with public transit system } \\
\text { before training (pre- and post- evaluation) }\end{array}$ & $\begin{array}{l}\text { A standardized pre- and post-evaluation test } \\
\text { can be an indicator of the instructors' skills } \\
\text { and competencies. It can explain if students } \\
\text { underwent training when they were younger }\end{array}$ \\
\hline $\begin{array}{l}\text { Trainers' method of communication with } \\
\text { student and parents/guardian }\end{array}$ & $\begin{array}{l}\text { Overcome feelings of anxiety or fear for } \\
\text { parents and students. Builds trust. }\end{array}$ \\
\hline $\begin{array}{l}\text { Tools and aides used to train students } \\
\text { Indicates students' preference of learning } \\
\text { style }\end{array}$ \\
\hline $\begin{array}{l}\text { Trainers', trainees'and parent(s)'/guardian(s)' } \\
\text { satisfaction levels associated with travel } \\
\text { training program (pre/during/post) }\end{array}$ & $\begin{array}{l}\text { Indicates attitudes towards travel training } \\
\text { program }\end{array}$ \\
\hline Trainers' experience level with travel training & Demonstrates experience level of trainer \\
\hline $\begin{array}{l}\text { What was the student's transit mode to and } \\
\text { from school before the Travel Training } \\
\text { Program? (bus or paratransit) }\end{array}$ & $\begin{array}{l}\text { Explains context of environment and } \\
\text { collaborative process }\end{array}$ \\
\hline
\end{tabular}

Figure 7 


\begin{tabular}{|l|r|r|r|}
\hline $\begin{array}{l}\text { BASE/REGULAR FARES } \\
\text { (as deducted from transit value in a Ventra transit } \\
\text { account) }\end{array}$ & Full & Reduced & Student \\
\hline 'L' train fare & $\$ 2.25^{\star}$ & $\$ 1.10$ & $\$ .75$ \\
\hline Bus fare & 2.00 & 1.00 & .75 \\
\hline Transfer (up to 2 additional rides within 2 hrs) & .25 & .15 & .15 \\
\hline
\end{tabular}

Figure 8

Source: http://www.transitchicago.com/fares/ 
Modes TO School

\begin{tabular}{|lcllc|}
\multicolumn{1}{c}{$\begin{array}{c}\text { Travel to } \\
\text { School }\end{array}$} & Students & $\begin{array}{c}\text { Yearly } \\
\text { school bus } \\
\text { cost per } \\
\text { student }\end{array}$ & $\begin{array}{l}\text { CTA Full } \\
\text { fare year } \\
\text { cost total }\end{array}$ & $\begin{array}{c}\text { CTA } \\
\text { Student } \\
\text { fare year } \\
\text { cost total }\end{array}$ \\
\hline 1 bus & 64 & $\$ 480,000$ & $\$ 23,040$ & $\$ 8,640$ \\
1 train & 9 & $\$ 67,500$ & $\$ 3,645$ & $\$ 1,215$ \\
1 bus 1 train & 12 & $\$ 90,000$ & $\$ 4,860$ & $\$ 1,944$ \\
2 buses & 80 & $\$ 600,000$ & $\$ 32,400$ & $\$ 12,960$ \\
2 buses 1 train & 5 & $\$ 37,500$ & $\$ 2,250$ & $\$ 945$ \\
2 trains & 1 & $\$ 7500$ & $\$ 450$ & $\$ 162$ \\
2 trains 1 bus & 2 & $\$ 1500$ & $\$ 990$ & $\$ 378$ \\
3 buses & 16 & $\$ 120,000$ & $\$ 7200$ & $\$ 3,024$ \\
N/A & 13 & $\$ 97,500$ & & \\
Totals & 202 & $\$ 1,501,500$ & $\$ 74,835$ & $\$ 29,268$ \\
\hline
\end{tabular}

Figure 9

Note: 13 students did not indicate mode of transit

Modes FROM School

\begin{tabular}{|lcllc|}
\hline \multicolumn{1}{|c}{$\begin{array}{c}\text { Travel from } \\
\text { School }\end{array}$} & Students & $\begin{array}{c}\text { Yearly } \\
\text { school bus } \\
\text { cost per } \\
\text { student }\end{array}$ & $\begin{array}{c}\text { CTA Full } \\
\text { fare year } \\
\text { cost total }\end{array}$ & $\begin{array}{c}\text { CTA } \\
\text { Student } \\
\text { fare year } \\
\text { cost total }\end{array}$ \\
\hline 1 bus & 64 & $\$ 480,000$ & $\$ 23,040$ & $\$ 8,640$ \\
1 train & 9 & $\$ 67,500$ & $\$ 3,645$ & $\$ 1,215$ \\
1 bus 1 train & 9 & $\$ 67,500$ & $\$ 3,645$ & $\$ 1,458$ \\
1 train 1 bus & 3 & $\$ 22,500$ & $\$ 1,350$ & $\$ 486$ \\
2 buses & 81 & $\$ 607,500$ & $\$ 32,805$ & $\$ 13,122$ \\
2 buses 1 train & 5 & $\$ 37,500$ & $\$ 2,250$ & $\$ 945$ \\
2 trains & 1 & $\$ 7,500$ & $\$ 450$ & $\$ 162$ \\
2 trains 1 bus & 2 & $\$ 15,000$ & $\$ 990$ & $\$ 378$ \\
3 buses & 15 & $\$ 112,500$ & $\$ 6,750$ & $\$ 2835$ \\
N/A & 13 & $\$ 97,500$ & & \\
Totals & 202 & $\$ 1,515,000$ & $\$ 74,925$ & $\$ 29,241$ \\
\hline
\end{tabular}

Figure 10

Note: 13 students did not indicate mode of transit 
Appendix A

The Chicago Public Schools collected data in the following 16 categories shown below:

- Student age

- Primary disability

- Gender

- Whether the student passed eligibility assessment and began training

- School year trained or assessed

- Whether student completed training and began traveling independently

- Date of completion or removal from program

- Reason student did not pass assessment or complete training

- Anticipated graduation date

- Case manager notification date

- Transition plan revision date

- Whether student was removed from transportation services in impact

- Number of training days

- Region (NE, NW, SE and SW)

- Number of buses or trains to school

- Number of buses or trains from school 
Appendix B

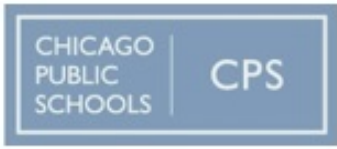

Office of Special Education \& Supports · 125 South Clark Street, Suite 800 - Chicago, Illinois 60603

\section{Travel Training Guidelines}

TRAVEL TRAINING is a process implemented at the school level to equip students with disabilities with the skills to travel independently via public transit. It is a fundamental precursor to achieving selfdetermined transition outcomes in education, employment, independent living, and community involvement.

PARENT/GUARDIAN SUPPORT is an essential component of the Travel Training process.

\section{Eligibility Criteria}

- $\quad$ Age 14 and above or transitioning to high school

- Minimum of $80 \%$ attendance during current school year

- Currently receiving Transportation as a Related Service on the IEP

- Students with a disciplinary history may be eligible for travel training, pending review by the Travel Training team

- $\quad$ The Parent/Guardian/Adult Students must agree that the student will be permanently removed from the yellow school bus upon successful completion of the training 


\section{Candidate Identification and Referral}

Referral for Travel Training services should be a collaborative decision made among the student, parent/guardian and the school community.

Student referral can be a result of, but not limited to the following:

- Parent/Guardian request

- Adult Student request

- Recommendations from special education service providers, school staff and/or school administration

- $\quad$ Presentations at Transition Fairs, Open Houses, Staff Orientation, Freshman Orientation, etc.

- $\quad$ Parent Outreach by school staff and administration via telephone/home visits

Once a student is identified as a potential candidate for Travel Training services, the person referring the student must complete the ONLINE REFERRAL FORM at www.cpsspecialeduction.org. Click on Supports and Services and then Travel Training Services.

- $\quad$ After the student referral form is submitted, the Travel Training Coordinator will send the case manager of the school (or designated point person) the Parent/Guardian/Adult Student Consent Form and Parent/Guardian/Adult Student Questionnaire within 10 school days.

- Once the Consent Form and Questionnaire Forms are completed and returned, a screener will be designated to administer an on-site screening of the student within 10 school days.

NOTE: PARENT/GUARDIAN/ADULT STUDENT CONSENT AND PARENT/GUARDIAN/ADULT STUDENT QUESTIONNAIRE FORMS MUST BE COMPLETED BY THE PARENT/GUARDIAN/ADULT STUDENT AND RETURNED TO THE REFERRAL SOURCE BEFORE TRAVEL TRAINING SERVICES CAN BEGIN.

* Schools are encouraged to obtain CTA Student Rider Permits from CTA Headquarters [located at 567 W. Lake St. $2^{\text {nd }}$ floor Sales Center, phone (312)681-7200] for students at the beginning of the school year. These permits serve as necessary identification for the student and reduce costs of Travel Training. These permits may be purchased at the cost of either the student or the school. 


\section{File Review and On-Site Screening}

After the referral process is complete, a Travel Trainer, Occupational Therapist, or Physical Therapist will conduct an on-site screening, consisting of the following:

\section{File Review}

- Most recent IEP

- Student's schedule

- Psychological Evaluation

- Social Assessment

- Medical History

- Attendance History

- $\quad$ Disciplinary file (if applicable)

\section{Observation}

- $\quad$ The student will be observed moving about the building and interacting with peers/staff in his/her natural environment (hallway, classroom, lunch area) over the course of the school day.

- The student not be aware of this observation, as not to create a circumstance where the student is likely to alter his/her typical behavior.

- Screeners are trained to identify situations that could compromise the student's safety in the community such as not recognizing personal space, staring, inappropriate touching, outbursts, gang signs, etc.

\section{After completing the file review and observation, the screener will:}

- $\quad$ Obtain and complete a Collateral Contact Note that will be included in the student's Travel Training file. A Collateral Contact Note is a written anecdotal log of the student's cognitive, social, or emotional skills as viewed by any professional who interacts with the student during the course of the school day.

- $\quad$ Email the Travel Training Coordinator to indicate that the on-site screening is complete.

- $\quad$ Schedule a meeting through the Travel Training Coordinator to discuss screening information. This gives the Travel Trainer an idea of the student's perceived abilities as expressed by staff members who have regular interaction with the student.

\section{If the student is recommended for assessment and the screening report has been received:}

- $\quad$ The Travel Training Coordinator will contact the student's parent to ensure they understand that the student will be removed from the yellow school bus once travel training has been successfully completed.

- $\quad$ Referral source, school, parent/guardian/adult student are notified of service start date.

\section{If the student is not recommended for assessment:}

- The screener submits a report detailing reasons, with recommendations to the IEP team.

- The recommendations can be used by the IEP team to drive goals and build student skills.

- The IEP team can work on identified needs with the student and collect progress data.

- $\quad$ A referral request can be re-submitted after 60 school days. 


\section{Travel Training Readiness Assessment}

After the screening process is complete, with a recommendation to proceed, a Travel Trainer will assess the student. The Travel Training assessment occurs over approximately 1-3 sessions and consists of the following:

\section{Student Observation}

- The Travel Trainer will spend time observing the student throughout the school building.

- The Travel Trainer will complete the STUDENT OBSERVATION form.

\section{Face-to-Face Interview}

- The Travel Trainer will assess the student's strengths and challenges in skill areas related to independent travel.

- The Travel Trainer will complete the FACE-TO-FACE INTERVIEW form.

Based on the results of the Student Observation and Face-to-Face Interview, the Travel Trainer will make a recommendation for the next step, Task Analysis.

SAFETY IS A MUST WHEN TRAVELING WITHIN A NATURAL COMMUNITY

ENVIRONMENT. IF THE STUDENT IS DEMONSTRATING UNSAFE BEHAVIOR THROUGH STUDENT OBSERVATION OR THE STUDENT'S INTERVIEW INDICATES TOO MANY RISK FACTORS AS DETERMINED BY THE TRAVEL TRAINER, THE TRAVEL TRAINER MAY NOT RECOMMEND THAT A TASK ANALYSIS BE COMPLETED.

\section{If the student is recommended for Task Analysis:}

- The student's referral source, school, and the parent/guardian/adult student will be notified of the decision by telephone and letter.

- The Travel Trainer will determine the student's route using RTA contact number (312) 836-7000 and additional available technologies.

- A TRAVEL TRAINING ROUTE form will be completed.

- Task Analysis will begin. The student's referral source, school, and parent/guardian/adult student will be notified of scheduled training dates and times.

If the student is not recommended for Task Analysis:

- The student's referral source, school, and the parent/guardian/adult student will be notified by telephone and letter.

- The Travel Trainer will make a recommendation to the parent/guardian/adult student and staff notifying them of additional instruction needed.

- Recommendations can assist IEP team with driving IEP goals to build student skills.

- Referral request can be re-submitted after 60 school days.

***A copy of the Student Observation form and Face-to-Face Interview form will be placed in the Travel Training database. 


\section{Task Analysis}

Task Analysis is the teaching tool used to provide Travel Training Services to the student within the community. The Task Analysis process is a maximum of 10 days. The Travel Trainer will use the Task Analysis form to complete this process.

THE TRAVEL TRAINER RESERVES THE RIGHT TO TERMINATE SERVICES AT ANY POINT THROUGHOUT THE TASK ANALYSIS PROCESS IF THE STUDENT EXIBITS BEHAVIOR THAT IS DEEMED TO BE UNSAFE OR DANGEROUS TO SELF AND/OR OTHERS. REASON FOR TERMINATION OF SERVICES WILL BE DOCUMENTED IN THE STUDENT'S FILE.

The Task Analysis process will consist of the following:

Days 1-5

- The Travel Trainer will provide travel training community-based instruction by addressing all areas on the Task Analysis form

Day 6

- The Travel Trainer will complete a written Progress Report to note the student's abilities and identify any possible areas of concern. The Progress report is included on the Task Analysis form.

Day 7-10

- The Travel Trainer will review the student's progress on the Task Analysis process and will work with the student to consolidate gains and/or work on areas of concern.

***A copy of the Task Analysis will be placed in the Travel Training database.

TRAVEL TRAINING SERVICES MAY BE COMPLETED PRIOR TO THE 10 DAY PERIOD IF THE STUDENT DEMONSTRATES MASTERY OF TASK ANALYSIS COMPONENTS, WITH NO AREAS OF CONCERN. 
Completion of Task Analysis/Post-Assessment

The Travel Trainer will complete Travel Training with the student on or before the $10^{\text {th }}$ day of the Task Analysis process. The Travel Trainer will conclude the Travel Training process by conducting a PostAssessment to review any areas of concern as identified through the Student Observation, the Face-toFace Interview and the Task Analysis. A summary of the Task Analysis process will also be included in the Post-Assessment. The Post-Assessment is on the Task Analysis Form.

The FINAL day (day 10 or sooner) of the Task Analysis process will consist of the following: Student Post-Assessment

- If the student had demonstrated any areas of need on the Face-to-Face Interview, the Travel Trainer may conduct a final interview of the student to review the areas of concern and to determine if the student has demonstrated improvement after undergoing the Task Analysis process.

- The Travel Trainer will assess the student by shadowing the student in the community (following the student on the travel training route using as few prompts and interventions as possible) to determine if the student is ready to self-travel.

- The Travel Training Coordinator will then allocate another Travel Trainer to ride the bus with the student to observe him/her traveling independently (unaware that they are being watched) to ensure the student is riding public transportation safely and correctly.

\section{Documentation of Results}

- In the Post-Assessment section of the Task Analysis form, the Travel Trainer will document progress on any areas of concern that were indicated in the Student Observation and Face to Face Interview.

- The Travel Trainer will document the results of the final day of the Task Analysis.

- The Travel Trainer will create a summary of the student's progress on the entire Task Analysis process in the Post-Assessment section of the Task Analysis form.

***A determination will be made based upon the results of the Post Assessment indicating whether or not the student is able to self-travel.

If the student has successfully completed the Task Analysis:

- A recommendation will be made for the student to self-travel.

- Recommendation will be documented on the Task Analysis Form.

- The school designee will remove the student from school bus services in IMPACT.

- $\quad$ Travel Trainer will provide the school with a copy of the IEP Revision Form to address the transportation section of the IEP.

If the student has not successfully completed the Task Analysis:

- A determination will be made that the student is not able to self-travel at this time.

- The reasons why student is not recommended for self-travel will be documented on Task Analysis form

- The recommendations can assist IEP team with driving IEP goals to build student skills

- A referral request can be re-submitted after 60 school days. 
Appendix C

\begin{tabular}{|c|c|c|c|c|c|}
\hline \multicolumn{6}{|c|}{ Student Age } \\
\hline & & Frequency & Percent & Valid Percent & $\begin{array}{c}\text { Cumulative } \\
\text { Percent }\end{array}$ \\
\hline \multirow[t]{5}{*}{ Valid } & $13-15$ & 44 & 16.2 & 16.2 & 16.2 \\
\hline & $16-17$ & 83 & 30.6 & 30.6 & 46.9 \\
\hline & $18-19$ & 95 & 35.1 & 35.1 & 81.9 \\
\hline & $20-21$ & 49 & 18.1 & 18.1 & 100.0 \\
\hline & Total & 271 & 100.0 & 100.0 & \\
\hline
\end{tabular}

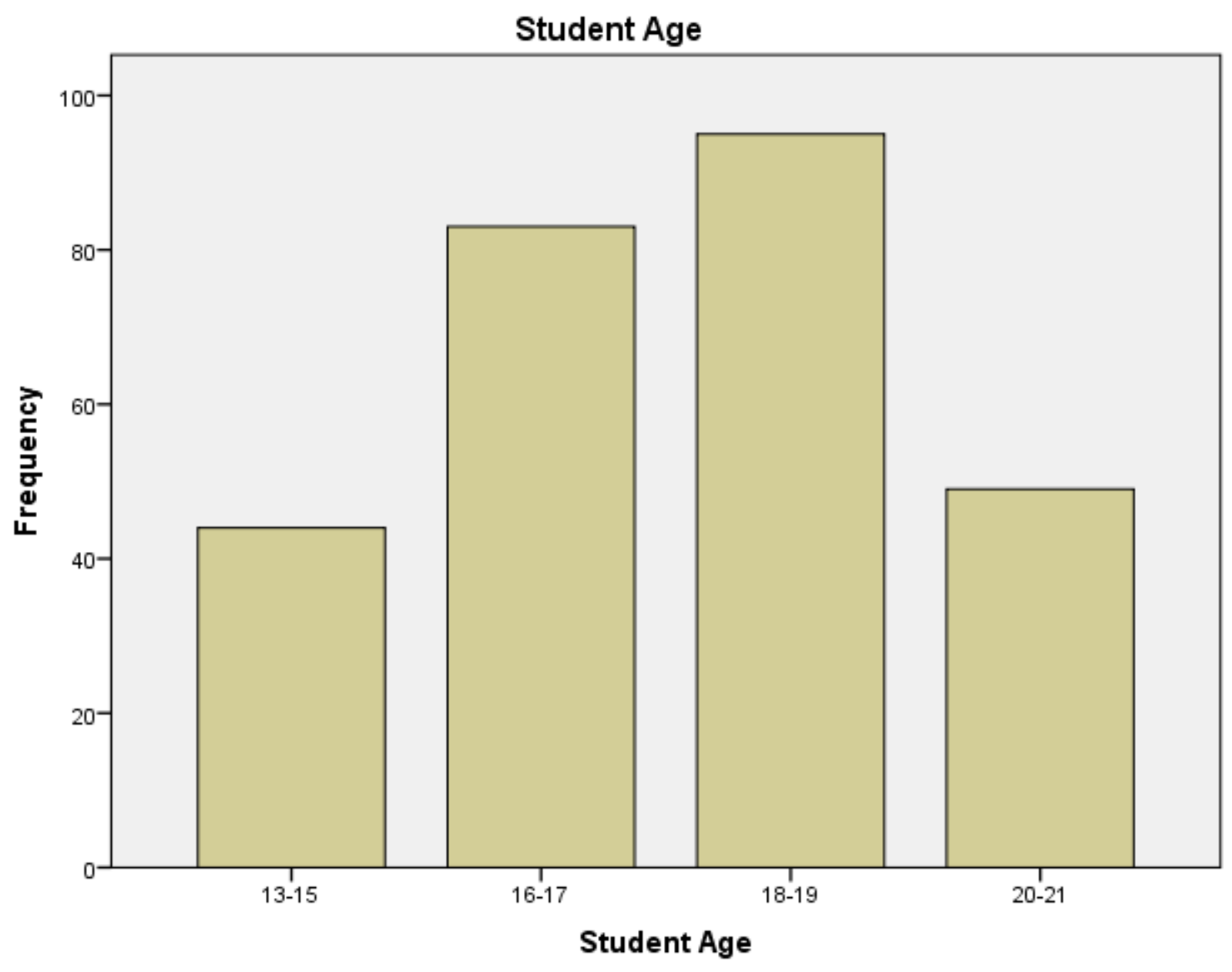


Primary Disability

\begin{tabular}{|c|c|c|c|c|c|}
\hline & & Frequency & Percent & Valid Percent & $\begin{array}{c}\text { Cumulative } \\
\text { Percent }\end{array}$ \\
\hline \multirow[t]{3}{*}{ Valid } & HI Disability & 118 & 43.5 & 43.5 & 43.5 \\
\hline & LI Disability & 153 & 56.5 & 56.5 & 100.0 \\
\hline & Total & 271 & 100.0 & 100.0 & \\
\hline
\end{tabular}

\section{Gender}

\begin{tabular}{|rr|r|r|r|r|}
\hline & & & & \multicolumn{2}{c|}{$\begin{array}{c}\text { Cumulative } \\
\text { Percent }\end{array}$} \\
\hline Valid & Frequency & Percent & Valid Percent & 29.2 \\
& Male & 79 & 29.2 & 29.2 & 100.0 \\
& 192 & 70.8 & 70.8 & \\
& Total & 271 & 100.0 & 100.0 & \\
\hline
\end{tabular}

Did Student Pass Assessment and Begin Training?

\begin{tabular}{|c|c|c|c|c|c|}
\hline & & Frequency & Percent & Valid Percent & $\begin{array}{c}\text { Cumulative } \\
\text { Percent }\end{array}$ \\
\hline \multirow[t]{3}{*}{ Valid } & No & 44 & 16.2 & 16.2 & 16.2 \\
\hline & Yes & 227 & 83.8 & 83.8 & 100.0 \\
\hline & Total & 271 & 100.0 & 100.0 & \\
\hline
\end{tabular}


School Year Trained or Assessed

\begin{tabular}{|c|c|c|c|c|c|}
\hline & & Frequency & Percent & Valid Percent & $\begin{array}{c}\text { Cumulative } \\
\text { Percent }\end{array}$ \\
\hline \multirow[t]{6}{*}{ Valid } & $2012-2013$ & 79 & 29.2 & 29.2 & 29.2 \\
\hline & 2013-2014 & 65 & 24.0 & 24.0 & 53.1 \\
\hline & 2014-2015 & 118 & 43.5 & 43.5 & 96.7 \\
\hline & 2015-2016 & 5 & 1.8 & 1.8 & 98.5 \\
\hline & Option 3 & 4 & 1.5 & 1.5 & 100.0 \\
\hline & Total & 271 & 100.0 & 100.0 & \\
\hline
\end{tabular}

Number of Training Days

\begin{tabular}{|c|c|c|c|c|c|}
\hline & & Frequency & Percent & Valid Percent & $\begin{array}{l}\text { Cumulative } \\
\text { Percent }\end{array}$ \\
\hline \multirow[t]{20}{*}{ Valid } & .0 & 29 & 10.7 & 10.7 & 10.7 \\
\hline & 1.0 & 28 & 10.3 & 10.3 & 21.0 \\
\hline & 2.0 & 20 & 7.4 & 7.4 & 28.4 \\
\hline & 3.0 & 24 & 8.9 & 8.9 & 37.3 \\
\hline & 4.0 & 17 & 6.3 & 6.3 & 43.5 \\
\hline & 5.0 & 30 & 11.1 & 11.1 & 54.6 \\
\hline & 6.0 & 27 & 10.0 & 10.0 & 64.6 \\
\hline & 7.0 & 19 & 7.0 & 7.0 & 71.6 \\
\hline & 8.0 & 24 & 8.9 & 8.9 & 80.4 \\
\hline & 9.0 & 18 & 6.6 & 6.6 & 87.1 \\
\hline & 10.0 & 8 & 3.0 & 3.0 & 90.0 \\
\hline & 11.0 & 4 & 1.5 & 1.5 & 91.5 \\
\hline & 12.0 & 5 & 1.8 & 1.8 & 93.4 \\
\hline & 13.0 & 10 & 3.7 & 3.7 & 97.0 \\
\hline & 14.0 & 4 & 1.5 & 1.5 & 98.5 \\
\hline & 15.0 & 1 & .4 & .4 & 98.9 \\
\hline & 16.0 & 1 & .4 & .4 & 99.3 \\
\hline & 18.0 & 1 & .4 & .4 & 99.6 \\
\hline & 20.0 & 1 & .4 & .4 & 100.0 \\
\hline & Total & 271 & 100.0 & 100.0 & \\
\hline
\end{tabular}




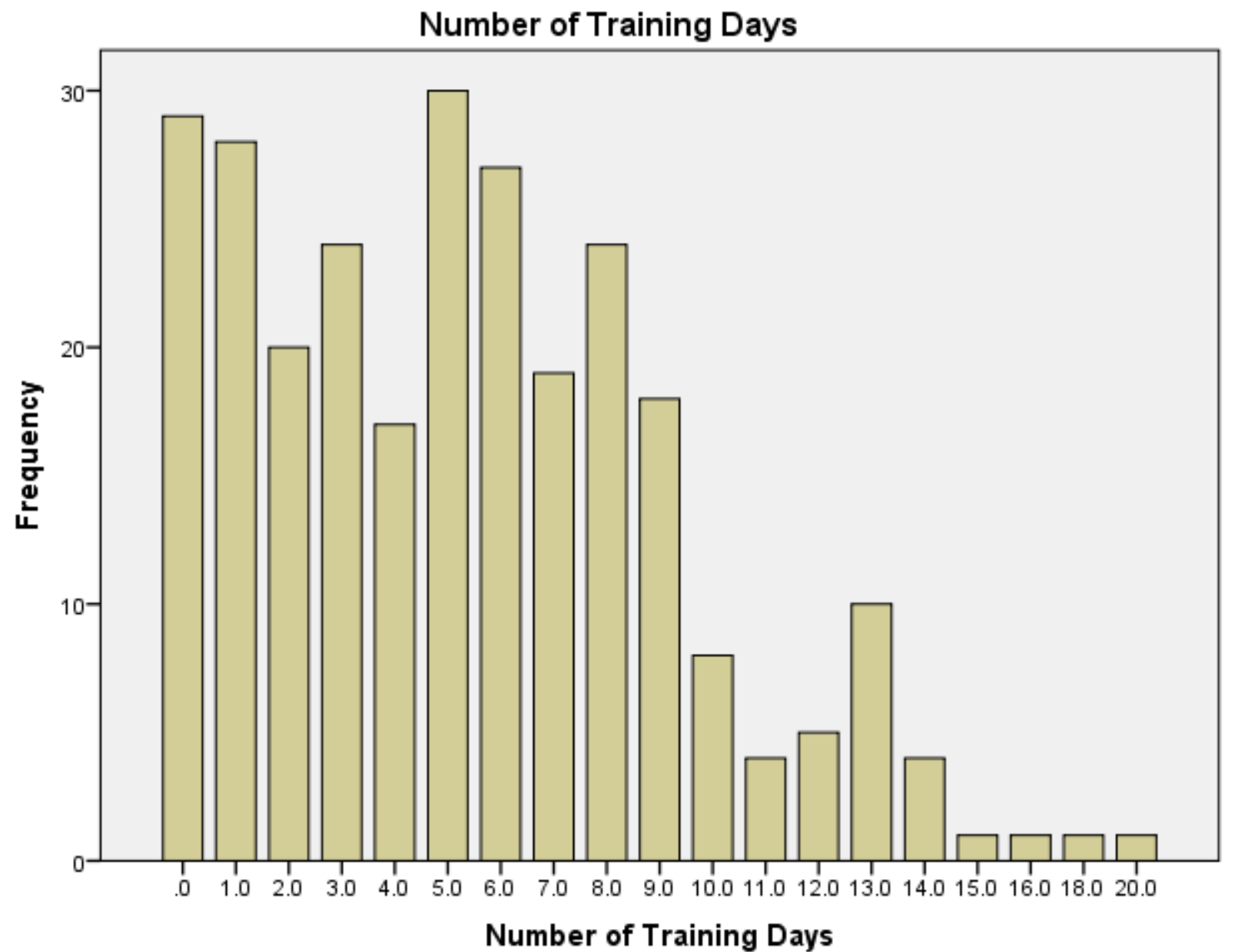

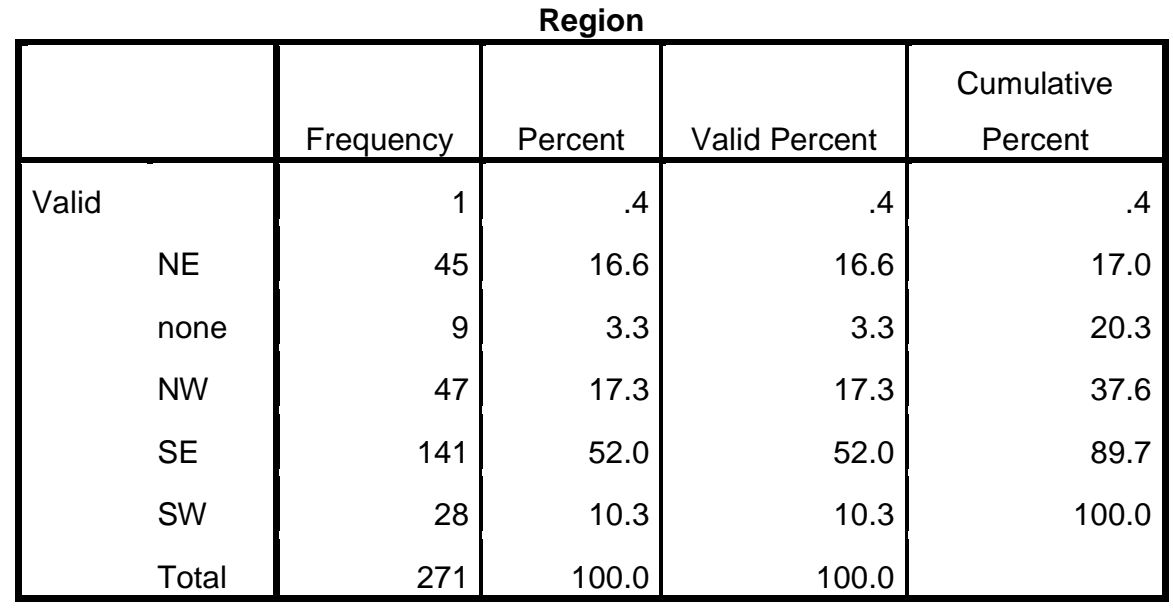

